\title{
Design and analysis of a waste gasification energy system with solid oxide fuel cells and absorption chillers
}

\section{Rokni, Masoud}

Published in:

International Journal of Hydrogen Energy

Link to article, DOI:

10.1016/j.ijhydene.2017.10.123

Publication date:

2018

Document Version

Peer reviewed version

Link back to DTU Orbit

Citation (APA):

Rokni, M. (2018). Design and analysis of a waste gasification energy system with solid oxide fuel cells and absorption chillers. International Journal of Hydrogen Energy, 43(11), 5922-5938.

https://doi.org/10.1016/j.ijhydene.2017.10.123

\section{General rights}

Copyright and moral rights for the publications made accessible in the public portal are retained by the authors and/or other copyright owners and it is a condition of accessing publications that users recognise and abide by the legal requirements associated with these rights.

- Users may download and print one copy of any publication from the public portal for the purpose of private study or research.

- You may not further distribute the material or use it for any profit-making activity or commercial gain

- You may freely distribute the URL identifying the publication in the public portal 


\title{
Design and Analysis of a Waste Gasification Energy System with Solid Oxide Fuel Cells and Absorption Chillers
}

\author{
"Masoud Rokni
}

\author{
Technical University of Denmark, Dept. Mechanical Engineering, Section for Thermal Energy \\ System, Copenhagen, 2800, Denmark \\ *E-mail:MR@mek.dtu.dk
}

\begin{abstract}
Energy saving is an open point in most European countries where energy policies are oriented to reduce the use of fossil fuels, greenhouses emissions and energy independence, and to increase the use of renewable energies. In the last several years, new technologies have been developed and some of them received subsidies to increase installation and reduce cost. This article presents a new sustainable trigeneration system (power, heat and cool) based on a solid oxide fuel cell (SOFC) system integrated with an absorption chiller for special applications such as hotels, resorts, hospitals, etc. with a focus on plant design and performance. The proposal system is based on the idea of gasifying the municipal waste, producing syngas serving as fuel for the trigeneration system. Such advanced system when improved is thus self-sustainable without dependency on net grid, district heating and district cooling. Other advantage of such waste to energy system is waste management, less disposal to sanitary landfills, saving large municipal fields for other human activity and considerable less environmental impact. Although plant electrical efficiency of such system is not significant but fuel utilization factor along with free fuel, significant less pollutant emissions and selfsustainability are importance points of the proposed system. It is shown that the energy efficiency of such small tri-generation system is more than $83 \%$ with net power of $170 \mathrm{~kW}$ and district energy of about $250 \mathrm{~kW}$.
\end{abstract}

Keywords: SOFC, municipal waste, gasification, absorption, energy system

\section{Introduction}

European countries are working to improve their energy policies of which main themes are energy saving and less pollutions. Installation of more efficient technology (such as condensing boilers, heat pumps, district cooling and district heating related to a cogeneration power plant) could help to achieve these goals. There is currently an increased interest in developing a distributed system of smaller-scale facilities at a single location, allowing electricity heat/cool to be produced and distributed close to the end user and thereby minimizing the costs associated with transportation [1] and [2]. Micro CHCP (combined heat, cool and power) for niche application falls also within this category. However, micro CHCPs face the problem of heat/cool-to power ratio that varies during the day as well as between the seasons due to the different consumption profile [3].

Municipal waste (MW) is one such type of biomass and is suitable for use in power plants. It presents some advantages such as the reduction of pollutants and greenhouse gas emissions and the possibility of reducing storage in landfills, as a result of which these spaces can be devoted to other human activities Waste management is becoming a matter of crucial importance for our societies. The massive increase in the production of waste during the last decades is followed by negative consequences in the environment, whereas also there is a vital amount of raw materials that are lost due to the lack of efficient waste treatment strategies. Hence, there is an urgent need for establishing efficient and innovative public policies concerning the handling and exploitation of waste. Traditionally waste disposal in sanitary landfills was the prevalent method related to waste management. Today this method is considered outdated due to the negative environmental impact 
that arise, as well as because of the high demand of large fields available for the waste disposal. A very good alternative to waste landfilling comprise the waste-to energy plants [4]. Currently the most mature technology is incineration, while gasification is still in the early stages of development. The remaining waste after established separation and recycling technologies in many countries (such as metals, plastics, hard papers, glass bottles and papers) would be very suitable for gasification. This is forming the basis idea of the current study.

Numerous studies have been investigated in the literature on SOFC-based hybrid systems that suggest high thermal efficiency. The majority of these studies use gas turbines as the bottoming cycle for SOFCs resulting in pressurized SOFC systems see e.g. [5]. Steam turbines and organic Rankine cycles (ORC) have also been used as a bottoming cycle, which resulted in non-pressurized SOFC stacks, see e.g. [6]. A few studies have been performed that utilize a Stirling engine as the bottoming cycle and the fuel cell as the topping cycle, see e.g. [2].

However, studies on combined SOFC-absorption chillers are very rare (e.g. [7]) considered the potential of combined SOFC-Absorption Chiller (AC) systems in Japanese office building without undergoing the detailed plant design and system operating performance. The emphasis was to indicate the market potential, $\mathrm{CO} 2$ emissions and decentralized energy system, rather than the detailed analysis and performance of the units. [8] studied the economics of such system in Hong Kong without experiencing fuel type and system design. [9], [10], [11] and [12] considered such system with pure methane, reformed gas and biogas as fuel. None of these works address (or looked into) integrated waste gasification with SOFC-AC combination. Other studies in SOFC for residential applications as cogeneration system can be found in e.g. [13], in which the feasibility of a $5 \mathrm{~kW} \mathrm{SOFC}$ from economical view was considered. A micro CHP with SOFC for single-family detached dwellings was studied in [14], while the impact of heat-to-power ratio for a SOFC based micro CHP for residential application in European climate was elaborated in [15]. Variation of the heat to power output ratio to match the electric and hot water demands of a Japanese residence can be found in [16].

[17] conducted a study of flue gas condensation for heat recovery of biomass boilers. An increase between 3 and $21 \%$ in primary energy efficiency was found depending on the flue gas outlet temperature. Temperatures as low as $-10^{\circ} \mathrm{C}$ was utilized in their analysis. They also concluded that even tough for large scale systems (more than 10MW) flue gas condensation is economically viable, but also for much smaller systems in particular if the added heating production can replace electric heaters.

This article presents a pioneering system based on an integrated waste gasification with SOFC and an absorption chiller for producing electricity, heat and cool. The study on such hybrid combination of a waste gasification plant integrated with a SOFC plant and an absorption chiller device is new and has not been deliberate elsewhere. A LiBr (Lithium Bromide) absorption chiller is chosen as a backup device to cover the cool demand while the SOFC and a heat recovery device cover the heat and electricity demands. The aim of this study is not only to present a system suitable for special applications (such as hotels, resorts and hospitals) but also to design a self-sustainable system that utilize the produced waste into energy (power, heat and cool). The waste should be handled after basic proven methods of recycling, which is considered as a critical problem for such particular applications.

\section{System Overview}

The main components of the system proposed here are a solid oxide fuel cell (SOFC) plant, an absorption chiller and a heating system (through water tank). The SOFC plant is fed by municipal waste for electricity production and at the same time to use its waste heat for production of district (domestic) heating and cooling. Figure 1 displays the integration of these components with each other. The waste heat drives firstly through an absorption chiller to produce district (or domestic) cooling. A district (or domestic) heating heat exchanger utilizes the rest of the energy as shown in the figure. Finally, a flue Gas Condensation (FGC) technique allows to further cooldown the waste heat and 
thereby increasing the cooling effect. A smart design may include a valve to regulate how much of the waste energy to be used for producing cooling or heating.

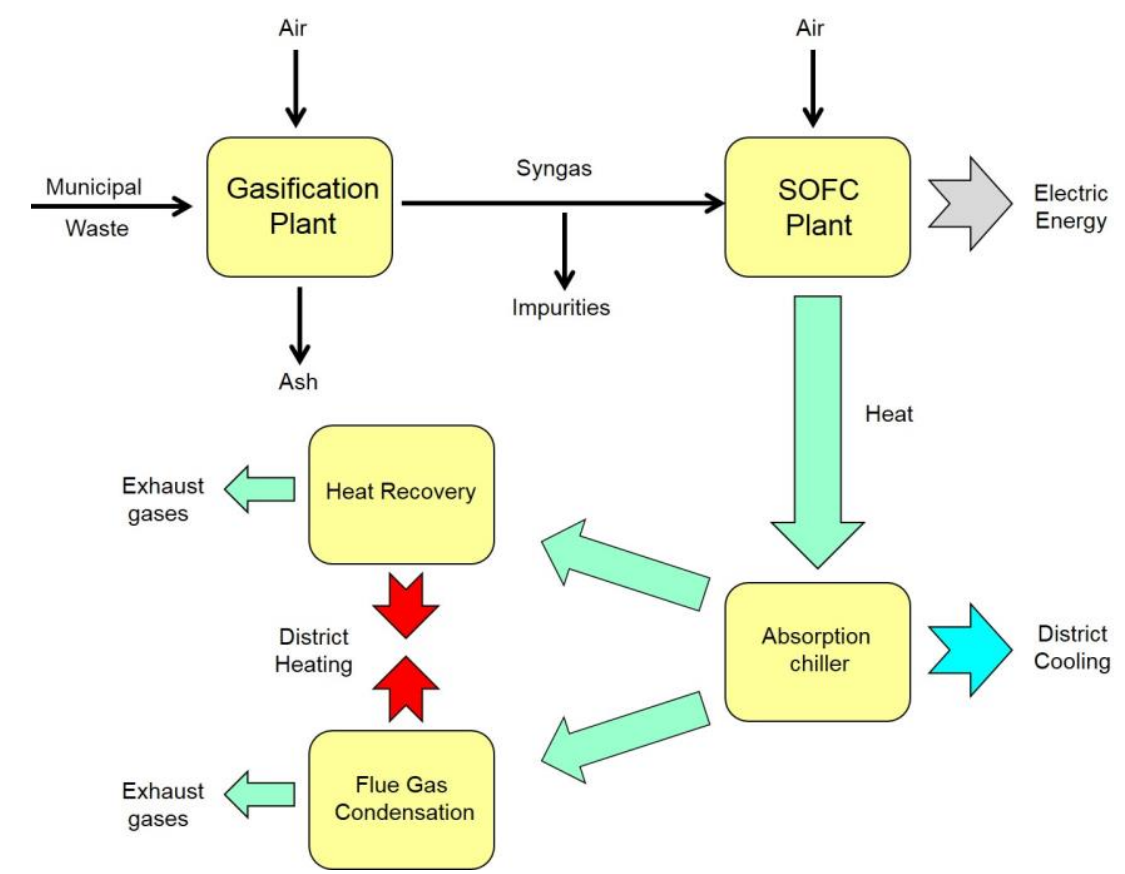

Figure 1: General scheme of the system proposed here with the main component and energy flows.

\section{Methodology and Modelling}

The thermodynamic results in this study are obtained from the Dynamic Network Analysis (DNA) simulation tool (see, e.g. [18]. This software is a result of an ongoing development process in the Thermal Energy Section of the Mechanical Department of the Technical University of Denmark. The program includes a component library, thermodynamic state models for fluids and standard numerical solvers for differential and algebraic equation systems. The component library models include heat exchangers, burners, turbo machinery, dryers, decanters, energy storages, valves and controllers, among others. The thermodynamic state models for fluids cover most of the basic fluids and such compounds as ash and tar for use in energy system analyses. DNA is a component-based simulation tool, meaning that the model is formulated by connecting components with nodes and adding operating conditions to build up a system. Next, the physical model is converted into a set of mathematical equations and solved numerically. The equations include mass and energy conservation for all components, and the nodes represent the relationships among the thermodynamic properties of the fluids in the system. The program is written in FORTRAN, and users may also contribute additional components and thermodynamic state models to the libraries. The calculation procedure is shown in Fig. 2.

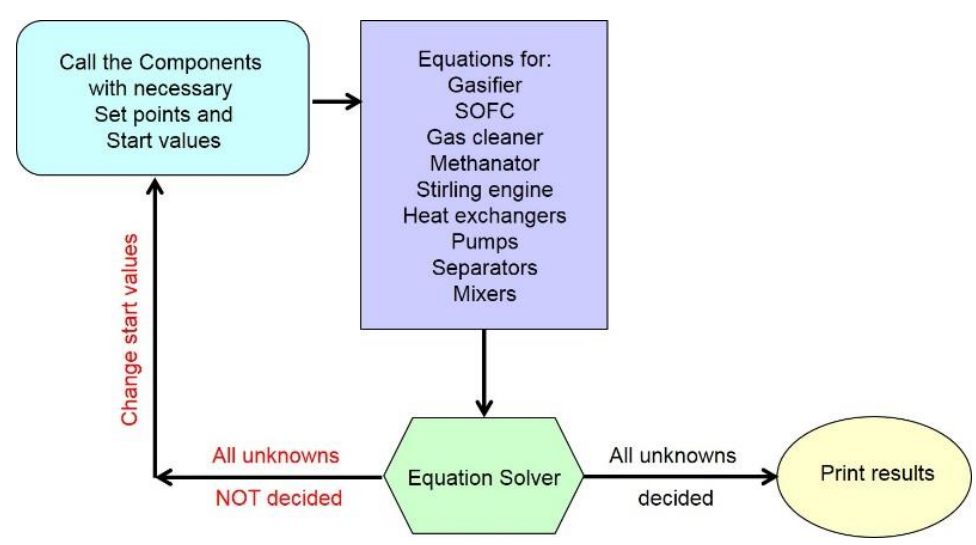


The energy efficiency of the plant can be expressed as the ratio between the summation of net electric power with the amount of district heating and district cooling production to the power of the fuel. With net electric power, it refers to the difference between the total produced power and the power used in the auxiliary components such as compressors, blowers, control systems, etc. The following equations express the electric efficiency and the energy efficiency defined in this study

$$
\begin{aligned}
& \eta_{\text {plant }}=\frac{P_{\text {Net }}+Q_{D H}+Q_{D C}}{\dot{m}_{\text {fuel }} L H V_{\text {fuel }}} \\
& \eta_{e l}=\frac{P_{\text {Net }}}{\dot{m}_{\text {fuel }} L H V_{\text {fuel }}}
\end{aligned}
$$

where $Q_{D H}$ and $Q_{D C}$ are the district heating (or domestic heating) and district cooling (or domestic cooling) respectively. $P_{N e t}$ is the net power of the plant, $L H V_{\text {fuel }}$ is the lower heating value of the fuel and $\dot{m}_{f u e l}$ is the mass flow of the fuel.

\subsection{Municipal Waste as Fuel}

Municipal waste (MW) may be seen as a renewable biomass feedstock utilized for energy production. To determine the potential for using it as fuel in energy systems, the type and composition of the waste must be evaluated. MW is considered as a combination of combustible and incombustible materials (see e.g. [19]). Food waste, paper, plastics and textiles are organic in nature are the primary contributors to the combustion. This is also true for food scraps which is a good candidate as fuel when combusted or gasified. Glass, metal and dirt are in general inorganic and therefore must be separated from combustible materials. This is the basis of this study that such there exists a wellmanaged separation technique in the society when handling the municipal wastes. During gasification most of the inorganic matter ends up in the ash, resulting in an ash with high metal concentrations

The heat released during combustion and moisture content varies greatly between different material fractions, making some materials more suitable for combustion than the others do. [20] collected a comprehensive data from almost hundred published articles, reports, books and cast them into an overview of physicochemical composition of individual material fractions comprising the waste in question. They presented data based on 11886 individual entries, median values and percentiles for 47 parameters in 11 individual waste fractions. Due to the heterogeneous nature of MW, the characteristics will vary depending on numerous factors, such as geographical region, income level, culture, etc. Therefore, the present investigation studies the effect of different wastes on plant performance.

\subsection{Gasifier Modeling}

The gasification plant used in this study is based on the model developed in a [21]. The model is briefly described here for clarity. A simple Gibbs reactor, where the total Gibbs free energy is minimized upon reaching chemical equilibrium, is implemented to calculate the gas composition at a specified temperature and pressure without considering the reaction pathways [22]. The Gibbs free energy of a gas (which is assumed to be a mixture of $\mathrm{k}$ perfect gases) is given by equation 2 . Each element in the inlet gas is in balance with the outlet gas composition, implying that the flow of each constituent has to be conserved. For $\mathrm{N}$ elements, such balance between inlet and outlet is then expressed by means of molar fraction. The $\mathrm{N}$ elements correspond to $\mathrm{H} 2, \mathrm{O} 2, \mathrm{~N} 2, \mathrm{CO}, \mathrm{NO}, \mathrm{CO} 2$, steam, NH3, H2S, SO2, CH4, C, NO2, HCN (hydrogen cyanide), COS (carbonyl sulfide), Ar, and ashes $(\mathrm{SiO} 2)$ in the gasification process. The number of atoms of $j$ element $(\mathrm{H}, \mathrm{C}, \mathrm{O}$, and $\mathrm{N})$ in each molecule of the entering compound $i$ is expressed by $\mathrm{H} 2, \mathrm{CH} 4, \mathrm{CO}, \mathrm{CO} 2, \mathrm{H} 2 \mathrm{O}, \mathrm{O} 2, \mathrm{~N} 2$, and Ar. 
Whereas the number of atoms of element $j$ in each molecule of the leaving compound $m$ is expressed by $\mathrm{H} 2, \mathrm{O} 2, \mathrm{~N} 2, \mathrm{CO}, \mathrm{NO}, \mathrm{CO} 2$, steam, NH3, H2S, SO2, CH4, C, NO2, HCN, COS, Ar, and ashes. The minimization of the Gibbs free energy is mathematically formulated by introducing a Lagrange multiplier $(\mu)$ for each of the $N$ constraints. By setting the partial derivative of this equation to zero with respect to molar outlet flow, then the corresponding function is minimized. Thus, a set of $k$ equations are defined for each chemical compound leaving the system. Finally, it is realizable that by assuming chemical equilibrium in the gasifier, the methane content in the product gas may be underestimated. Therefore, a parameter called METHANE is applied to allow some of the methane to bypass the gasifier without undergoing any chemical reactions. The value of this parameter is assumed to be 0.01 , meaning that $1 \%$ of the methane bypassed the gasifier. It may be noted that other values can be selected but due to the lack of experimental data, further investigations on the choice of this value are not conducted. Note also, [23] applied such method successfully for biomass gasification and the results agreed very well with the experimental data, as demonstrated in Table 1.

Table 1. Comparison between modeling results and Experimental data from [24].

\begin{tabular}{r|c|c}
\hline Parameter & Experiment [19 & Modeled gasifier \\
\hline $\mathrm{H}_{2}($ vol \%) & 30.5 & 29.9 \\
$\mathrm{CO}($ vol \%) & 19.6 & 20.8 \\
$\mathrm{CO}_{2}($ vol \%) & 15.4 & 13.5 \\
$\mathrm{CH}_{4}($ vol \%) & 1.16 & 1.19 \\
$\mathrm{~N}_{2}($ vol \%) & 33.3 & 34.2 \\
$\mathrm{H}_{2} \mathrm{~S}(\mathrm{ppmv})$ & $<1$ & $<1$ \\
$\mathrm{LHV}(\mathrm{MJ} / \mathrm{kg})$ & 6.2 & 6.3 \\
Cold gas efficiency $(\%)$ & 93 & 94 \\
\hline
\end{tabular}

$$
\eta_{\text {coldgas }}=\frac{\dot{m}_{\text {cold gas }} L H V_{\text {cold gas }}}{\dot{m}_{\text {biomass }} L H V_{\text {biomass }}}
$$

Figure 3 displays the gasification plant modelled here. MW is fed continuously to a dryer, in which most of the moisture is removed via steam (steam loop). In reality, the dryer works also as pyrolyzer. The dried waste feeds the gasifier while the moisture removed from the waste will mix with preheated air before entering the gasifier (other side of the gasifier). A small pump in the colder side of the steam loop is the driver of the loop and ensures continuous supply of the steam to the gasifier. A heat exchanger (GAP in the figure) preheats the air and ensures continuous feeding of air to the gasifier. Thus, preheated air and moisture removed from the fuel mixes together to a temperature close to the operating temperature of the gasifier before feeding to it. The gases out of the gasifier preheats the entering air (through GAP heat exchanger) as well as the steam loop (through SG heat exchanger). This study assumes that waste preheats from $15^{\circ} \mathrm{C}(298 \mathrm{~K})$ to $150^{\circ} \mathrm{C}(423 \mathrm{~K})$ by steam loop from $200^{\circ} \mathrm{C}(473 \mathrm{~K})$ to $150^{\circ} \mathrm{C}(423 \mathrm{~K})$. These temperatures are based on the gasifier presented in [24]. A comprehensive gas cleaning system removes all particles that may be harmful for the fuel cell such as chlorine, sulfur, etc. [25] discussed and presented the syngas compositions systematically by taking into account the syngas cleaning system.

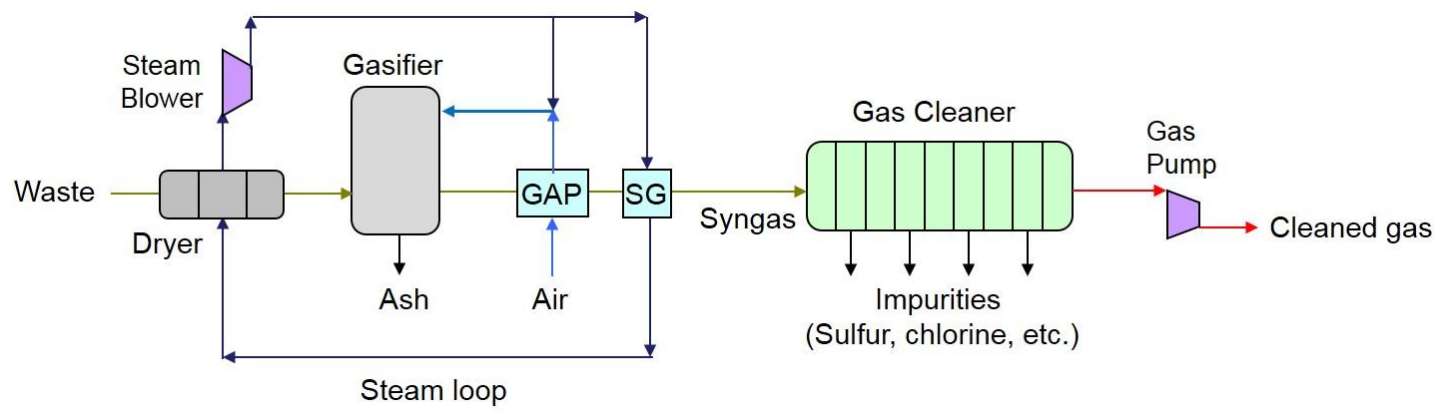

Figure 3: Gasifier plant modelled in this study. 
Table 2 shows the MW composition and the properties used in this study, which is based on a previously published study [26]. The only difference is that a very small amount of chlorine is also added into the composition $(0.2 \%)$. It may be noted that the compositions are expressed on a dry basis (i.e., weight fraction without moisture content).

Tabel 2: Municipal waste compositions used in this study.

\begin{tabular}{c|c}
\hline Municipal Waste Composition & Dry-based \\
\hline $\mathrm{C}(\%)$ & 47.6 \\
$\mathrm{H}(\%)$ & 6 \\
$\mathrm{O}(\%)$ & 32.9 \\
$\mathrm{~S}(\%)$ & 0.3 \\
$\mathrm{~N}(\%)$ & 1.2 \\
$\mathrm{Ash}(\%)$ & 11.8 \\
$\mathrm{Cl}(\%)$ & 0.2 \\
$\mathrm{LHV}(\mathrm{kJ} / \mathrm{kg}),($ dry basis $)$ & 19879 \\
$c_{p}(\mathrm{~kJ} / \mathrm{kg})$ & 1.71 \\
Moisture $(\%)$ & 9.5 \\
\hline
\end{tabular}

\subsection{SOFC Modeling}

The SOFC model in this study aims at representing the performance of the second-generation SOFC stacks developed by Topsoe Fuel Cell A/S (TOFC) and the Fuel Cells and Solid State Chemistry Division at Ris $\varnothing-D T U$ (Technical University of Denmark). Such SOFC type is an anode supported cell with a Ni/YSZ ${ }^{1}$ anode, an YSZ electrolyte, and an $\mathrm{LSM}^{2} / \mathrm{YSZ}$ cathode [27]. Anode thickness is $600 \mu \mathrm{m}$, electrolyte thickness is $50 \mu \mathrm{m}$ and cathode thickness is $10 \mu \mathrm{m}$. The SOFC stack model used in this study is the results of previous investigations such as in [28] and [23]. As shown later, the model agrees very well with the experimental data at different cell operating temperatures. For sake of clarification, the model is briefly described here. The model is assumed to be zerodimensional, enabling for application in a general computer code for calculating complicated energy systems. In such modeling, one must distinguish between electro -chemical modeling, the calculation of cell irreversibility (cell voltage efficiency) and the calculation of the species compositions at the outlet. For the electrochemical modeling, the operational voltage $\left(E_{c e l l}\right)$ can be found as:

$$
E_{\text {cell }}=E_{\text {Nernst }}-\Delta E_{\text {act }}-\Delta E_{\text {ohm }}-\Delta E_{\text {conc }}
$$

where $E_{\text {Nernst }}, \Delta E_{a c t}, \Delta E_{\text {ohm }}$ and $\Delta E_{\text {conc }}$ are the Nernst ideal reversible voltage, activation polarization, ohmic polarization and concentration polarization, respectively. Assuming that only hydrogen is electrochemically converted then the Nernst equation can be written as

$$
\begin{aligned}
& E_{\text {Nernst }}=\frac{-\Delta g_{\mathrm{f}}{ }^{0}}{n_{\mathrm{e}} F}+\frac{R T}{n_{\mathrm{e}} F} \ln \left(\frac{p_{\mathrm{H}_{2}, \mathrm{tot}} \sqrt{p_{\mathrm{O}_{2}}}}{p_{\mathrm{H}_{2} \mathrm{O}}}\right) \\
& p_{\mathrm{H} 2, \mathrm{tot}}=p_{\mathrm{H} 2}+p_{\mathrm{CO}}+4 p_{\mathrm{CH} 4}
\end{aligned}
$$

where $\Delta g_{f}^{0}$ is the Gibbs free energy (for $\mathrm{H}_{2}$ reaction) at standard pressure. The water-gas shift reaction is very fast; therefore, the assumption that hydrogen is the only species to be electrochemically

\footnotetext{
${ }^{1}$ Yttria-stabilized zirconia.

${ }^{2}$ Lanthanum strontium manganite.
} 
converted is justified (see [29] and [30]). Because the electrochemical oxidation rate of $\mathrm{H} 2$ is much higher than that of $\mathrm{CO}$, then it can be assumed that hydrogen is the only species that can convert electrochemically (see e.g. [31]). In the above equations, $p_{\mathrm{H} 2}$ and $p_{\mathrm{H} 2 \mathrm{O}}$ are the partial pressures for $\mathrm{H} 2$ and $\mathrm{H} 2 \mathrm{O}$, respectively.

The activation polarization can be evaluated from the Butler-Volmer equation, which is isolated from other polarizations to determine the charge transfer coefficients and exchange current density from the experimental date available for different cell operating temperatures, using the curve fitting technique (see, e.g. [30]).

$$
\Delta E_{a c t}=\Delta E_{a c t, c}+\Delta E_{a c t, a}=\frac{2 R T}{F}\left[\sinh ^{-1}\left(\frac{i+i_{\mathrm{n}}}{2 i_{0, \mathrm{a}}}\right)+\sinh ^{-1}\left(\frac{i+i_{\mathrm{n}}}{2 i_{0, \mathrm{c}}}\right)\right]
$$

The ohmic polarization depends on the electrical conductivity of the electrodes as well as the ionic conductivity of the electrolyte (see, e.g. [32]). This polarization is also calibrated against experimental (for different cell operating temperatures) data for a cell with anode, electrolyte and cathode thicknesses of $600 \mu \mathrm{m}, 50 \mu \mathrm{m}$ and $10 \mu \mathrm{m}$, respectively.

$$
\Delta E_{o h m}=\left(\frac{t_{a n}}{\sigma_{a n}}+\frac{t_{e l}}{\sigma_{e l}}+\frac{t_{c a}}{\sigma_{c a}}\right) i_{d}
$$

where $t_{a n}, t_{e l}$ and $t_{c a}$ are the anode thickness, electrolyte thickness and cathode thickness, respectively. $\sigma_{a n}, \sigma_{e l}$ and $\sigma_{c a}$ are the conductivities of the anode, electrolyte and cathode, respectively. $\sigma_{e l}$ is a function of temperature, see [23]

The concentration polarization is dominant at high current densities for anode-supported SOFCs, wherein insufficient amounts of reactants are transported to the electrodes and the voltage is then reduced significantly. Again, the concentration polarization is calibrated against experimental data (for different cell operating temperatures) by introducing the anode limiting current (see, e.g. [33]), in which the anode porosity and tortuosity are also included, among other parameters.

$$
\Delta E_{\text {conc }}=B\left(\ln \left(1+\frac{p_{H 2} i_{d}}{p_{H 2 O} i_{a s}}\right)-\ln \left(1-\frac{i_{d}}{i_{a s}}\right)\right)
$$

where $B$ is the diffusion coefficient and temperatures dependent. It is then calibrated using experimental data, see [23].

The fuel composition at the anode outlet is calculated using the Gibbs minimization method, as described in [22]. Equilibrium at the anode outlet temperature and pressure is assumed for the following species: $\mathrm{H}_{2}, \mathrm{CO}, \mathrm{CO}_{2}, \mathrm{H}_{2} \mathrm{O}, \mathrm{CH}_{4}$ and $\mathrm{N}_{2}$. Thus, the Gibbs minimization method calculates the compositions of these species at the outlet by minimizing their Gibbs energies. The equilibrium assumption is fair because the methane content in this study is very low. The methane content is mainly depended on the kinetic parameters rather than the chemical equilibrium and its reaction rate is fast [34].

To calculate the voltage efficiency of the SOFC cells, the power production from the SOFC $\left(P_{S O F C}\right)$ depends on the amount of chemical energy fed to the anode, the reversible efficiency $\left(\eta_{\text {rev }}\right)$, the voltage efficiency $\left(\eta_{v}\right)$ and the fuel utilization factor $\left(U_{F}\right)$. It is defined in mathematical form as

$$
P_{\text {SOFC }}=\left(L H V_{\mathrm{H}_{2}} \dot{n}_{\mathrm{H}_{2}, \text { in }}+L H V_{C O} \dot{n}_{C O, \text { in }}+L H V_{\mathrm{CH}_{4}} \dot{n}_{\mathrm{CH}_{4}, \text { in }}\right) \eta_{\text {rev }} \eta_{v} U_{F}
$$

where $U_{F}$ is a set value and $\eta_{v}$ is defined as 


$$
\eta_{\mathrm{v}}=\frac{\Delta E_{\mathrm{cell}}}{E_{\text {Nernst }}}
$$

The reversible efficiency is the maximum possible efficiency, defined as the relationship between the maximum electrical energy available (change in Gibbs free energy) and the fuel's lower heating value (LHV) as follows (see, e.g. [35]):

$$
\begin{aligned}
\eta_{\text {rev }}= & \frac{\left(\Delta \bar{g}_{f}\right)_{\text {fuel }}}{L H V_{\text {fuel }}} \\
\left(\Delta \bar{g}_{f}\right)_{\text {fuel }} & =\left[\left(\bar{g}_{f}\right)_{\mathrm{H}_{2} \mathrm{O}}-\left(\bar{g}_{f}\right)_{\mathrm{H}_{2}}-\frac{1}{2}\left(\bar{g}_{f}\right)_{\mathrm{O}_{2}}\right\rfloor y_{\mathrm{H}_{2}, \text { in }}+\left\lfloor\left(\bar{g}_{f}\right)_{\mathrm{CO}_{2}}-\left(\bar{g}_{f}\right)_{\mathrm{CO}}-\frac{1}{2}\left(\bar{g}_{f}\right)_{\mathrm{O}_{2}}\right\rfloor y_{\mathrm{CO}, \text { in }} \\
& +\left[\begin{array}{l}
\left(\bar{g}_{f}\right)_{\mathrm{CO}_{2}}+2\left(\bar{g}_{f}\right)_{\mathrm{H}_{2} \mathrm{O}}-\left(\bar{g}_{f}\right)_{\mathrm{CH}_{4}} \\
-2\left(\bar{g}_{f}\right)_{\mathrm{O}_{2}}
\end{array}\right] y_{\mathrm{CH}_{4}, \text { in }}
\end{aligned}
$$

The partial pressures are assumed to be the average of the inlet and outlet temperatures,

$$
\begin{aligned}
& \bar{p}_{\mathrm{O}_{2}}=\left(\frac{y_{\mathrm{O}_{2}, \text { out }}+y_{\mathrm{O}_{2}, \text { in }}}{2}\right) \bar{p}_{\mathrm{c}} \\
& \bar{p}_{j}=\left(\frac{y_{j, \text { out }}+y_{j, \text { in }}}{2}\right) \bar{p} \quad j=\left\{\mathrm{H}_{2}, \mathrm{CO}, \mathrm{CH}_{4}, \mathrm{CO}_{2}, \mathrm{H}_{2} \mathrm{O}, \mathrm{N}_{2}, A r\right\}
\end{aligned}
$$

A comparison between the SOFC model developed here and the experimental data is shown in Fig. 4, in terms of current density and cell voltage (IV curve). As seen from the figure, the model captures the experimental data very well at four different cell operating temperatures from $650^{\circ} \mathrm{C}$ to $800^{\circ} \mathrm{C}$, with a standard error of less than 0.01 . Different $\mathrm{H} 2$ and water vapor concentrations were used when developing the model. However, only the data for $97 \% \mathrm{H} 2$ with $3 \%$ water vapor is shown in Fig. 4. In addition, equations for the conservation of mass (with molar flows), conservation of energy and conservation of momentum are also included in the model. The reliability of the models presented here is justified in [2] with different fuels such natural gas, ethanol, and methanol. For example, the calculated plant efficiencies by the current model agrees very well with the data presented in the literature for similar plant design. Table 3 displays the main parameters for the SOFC stacks used in this study.

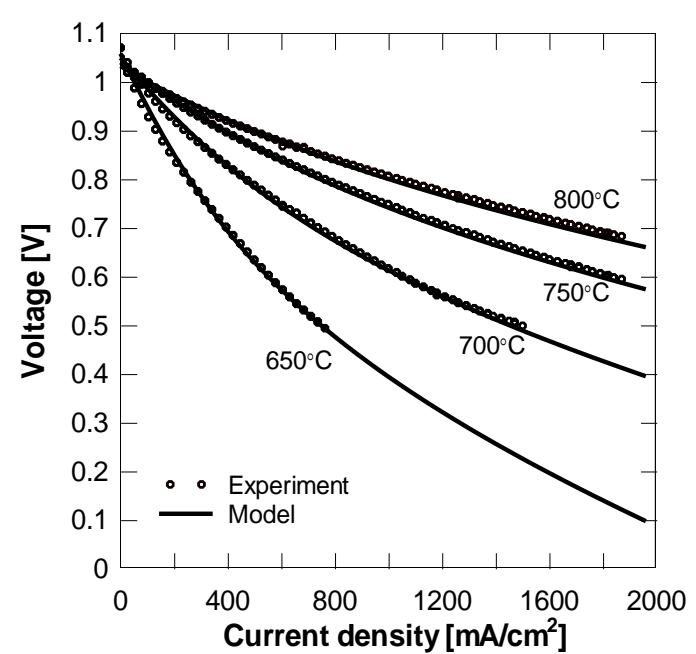

Figure 4: Cell voltage versus current density and a comparison between the modelling results and experimental data with $97 \%$ H2 and $3 \%$ water vapor. 
323

324

325

326

327

328

329

330

331

332

333

334

335

336

337

338

339

340

341

342

343

344

345

346

347

348

349

350

351

352

353

354

355

356

357

358

359

360

361

362

363
Table 3: The main SOFC parameters used in this study.

\begin{tabular}{c|c}
\hline Parameter & Value \\
\hline Fuel utilization factor & 0.675 \\
Number of cells in stack & 75 \\
Number of stacks & 160 \\
Cathode pressure drop ratio (bar) & 0.04 \\
Anode pressure drop ratio $($ bar $)$ & 0.01 \\
Cathode inlet temperature $\left({ }^{\circ} \mathrm{C}\right)$ & 600 \\
Anode inlet temperature $\left({ }^{\circ} \mathrm{C}\right)$ & 650 \\
Outlet temperatures $\left({ }^{\circ} \mathrm{C}\right)$ & 780 \\
\hline
\end{tabular}

\subsection{Lithium Bromide Absorption Chiller Modeling}

Refrigeration systems based on vapor absorption cycles are a well-known technology, which has extensively been studied for many years [36]. Nevertheless, their market share is still limited compared to the vapor compression systems. The fundamental reasons for this aspect are the relatively low efficiency in delivering cooling needs as well as the high initial capital costs. Regarding the Coefficient Of Performance (COP), which is defined as the ratio between the achieved cooling capacity and the heat input to the cycle. Its value is usually lower than 1 (typically within 0.5 to 0.9 ), while vapor compression cycles display value higher than 3 based on the electrical input [37] and [38]. Despite their disadvantages, the utilization of absorption cycles is significantly favored when waste heat is available. More specifically, it is very often the case when hot exhaust gases resulting from industrial processes are released in the surroundings. Thus the integration of absorption chillers, which will utilize this heat that otherwise would be wasted, can lead to an increase in the overall efficiency of the plant.

The driving force of an absorption cycle is a solution consisting of a refrigerant and an absorbent. In most cases the mixture water with lithium-bromide or, water with ammonia is utilized. Furthermore, the cycles can be single, double or triple effect, depending on the available waste heat temperature and the potential investment. In general, multistage cycles need higher temperature heat sources and are characterized by higher values of COP compared to the single stage ones. On the other hand, the installation is more complex since larger number of components will be required which results in higher capital costs [39]. This study uses the mixture of water with lithium-bromide (LiBr) and Fig. 5 shows the absorption plant designed in this study.

The absorber creates a low-pressure area that sucks a flow of refrigerant (steam) from the evaporator and it causes that the refrigerant, which is in vapor form, to condense into water. The diluted LiBr-water solution (a high content of water) is then pumped to meet the high-pressure level. It is important to underline that lifting a liquid to a higher-pressure level is "cheaper" than lifting a gas in a compressor, which is why the pump work is close to negligible when comparing to an electric vapor compression refrigeration cycle. This weak solution feeds to the desorber/generator where heat input boils the refrigerant from the absorbent. The free refrigerant (water/steam) continues towards the condenser to reject heat before its pressure decreases in an expansion valve. The re-concentrated (rich) $\mathrm{LiBr}$ from the desorber returns to the absorption loop through a solution valve where its pressure decreases to the low pressure before entering the absorber. The low-pressure refrigerant then passes through an evaporator to evaporate before entering the absorber. Thus, the other side of the evaporator will be the cooling demand. In this study, it is assumed that the cooling flow enters the evaporator at $11^{\circ} \mathrm{C}(284 \mathrm{~K})$ and leaves it at $4^{\circ} \mathrm{C}(277 \mathrm{~K})$.

Note that in the present study, the heat input will be the waste heat from the SOFC plant. Both the absorber and condenser reject heat to a cooling liquid such as water. This investigation assumes that the cooling liquid enters to the absorber with a temperature of $15^{\circ} \mathrm{C}(298 \mathrm{~K})$, then continuous to the condenser and leaves it with $32^{\circ} \mathrm{C}(303 \mathrm{~K})$, as stated in Table 4 . 


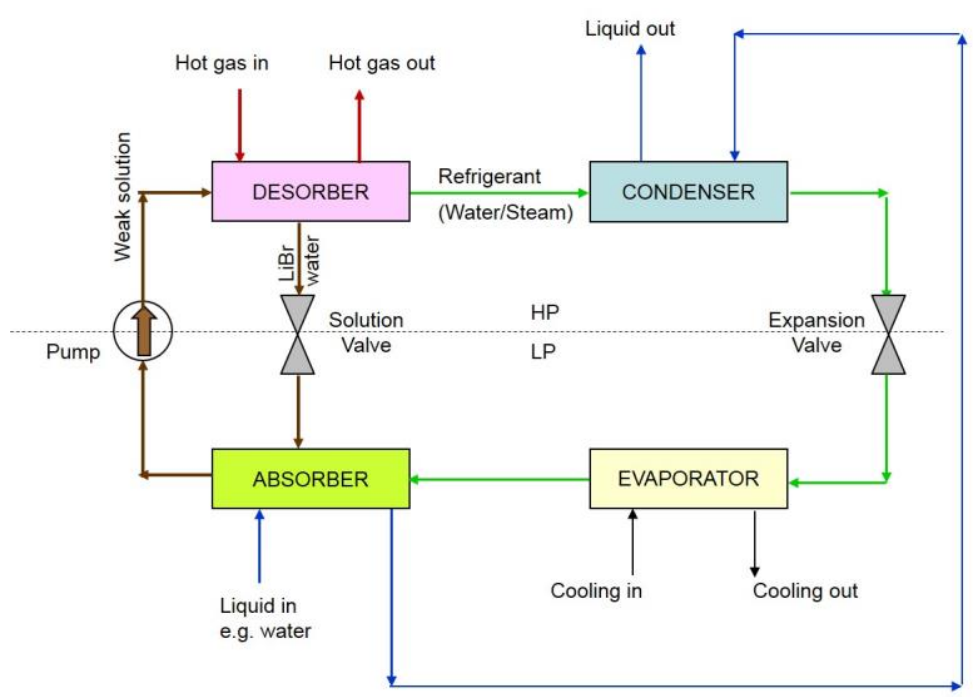

Figure 5: The absorption plant. $L P=$ Low pressure, $H P=$ high pressure.

In this study, lithium-bromide solution is used by taking into count the properties of this mixture such as enthalpy; entropy and heat capacity are accounted (see e.g. [40]). Table 4 shows parameters used in this study for the absorption chiller.

Table 4: The main parameters for absorption chiller, basic case.

\begin{tabular}{c|c}
\hline Parameter & Value \\
\hline Desorber gas outlet temperature $\left({ }^{\circ} \mathrm{C}\right)$ & 135 \\
Rich solution $(-)$ & 0.593 \\
Week solution $(-)$ & 0.548 \\
Condenser outlet temperature $\left({ }^{\circ} \mathrm{C}\right)$ & 32 \\
Rich solution pressure after valve $($ bar $)$ & 0.008 \\
Absorber cooling inlet temperature $\left({ }^{\circ} \mathrm{C}\right)$ & 15 \\
Absorber cooling inlet pressure $($ bar $)$ & 16 \\
Solution pump pressure (bar) & 0.05 \\
\hline
\end{tabular}

\subsection{District (Domestic) Heating}

The temperature out of the desorber is rather high $\left(135^{\circ} \mathrm{C}, 408 \mathrm{~K}\right)$ which allows to further use the available heat from the off-gases. This can be done using a district heating heat exchanger. Assuming the $4^{\text {th }}$ generation district heating system then forward temperature of the water can be as low as $60^{\circ} \mathrm{C}$ $(333 \mathrm{~K})$. Thus the allowing a pinch temperature of $10^{\circ} \mathrm{C}$, then the off-gases temperature can be cooled down to $70^{\circ} \mathrm{C}(343 \mathrm{~K})$ which is still above the dew point of the off-gases. In the present study the feed-water and return temperatures of the district heating water is assumed being $60^{\circ}(273 \mathrm{~K})$ and $25^{\circ} \mathrm{C}(298 \mathrm{~K})$ respectively. Such feed temperature is the most common value of the $4^{\text {th }}$ generation district heating in Denmark. Such temperatures suits very well for local decentralized district heating also. Note that the district heating can be used for both space heating and hot water production (showering and washing purposes).

\subsection{Modelling of Compressors and Heat Exchangers}

The pumps power consumption is calculated as

$$
W_{\text {pump }}=\left[\frac{\dot{m} v_{\text {in }}\left(p_{\text {out }}-p_{\text {in }}\right)}{\eta_{\text {pump }}}\right]_{\text {pump }}
$$


where $\dot{m}, p, v$ and $\eta_{\text {pump }}$ are the mass flow, pressure, specific volume $\left(\mathrm{m}^{3} / \mathrm{kg}\right)$ and efficiency of the pump respectively. The pump efficiency and outlet pressure is defined as shown below. The power consumption for compressors are modeled based on the definition of isentropic and mechanical efficiencies (given values) as

$$
\begin{aligned}
& \eta_{\text {is }}=\left[\frac{h_{\text {out }, \text { Sin }}-h_{\text {in }}}{h_{\text {out }}-h_{\text {in }}}\right]_{\text {compressor }} \\
& \eta_{m}=\left[\frac{\dot{m}\left(h_{\text {out }}-h_{\text {in }}\right)}{W}\right]_{\text {compressor }}
\end{aligned}
$$

398

where and $h_{\operatorname{Sin}}$ is the enthalpy when entropy kept constant as for inlet.

In modeling the heat exchanger, they are assumed to be counter-flows and it is assumed that all energy from one side is transferred to the other side by neglecting the heat losses, (see e.g. [41]). In modeling of the heat exchangers for the absorption chiller, a pinch temperature is given as

$$
\begin{aligned}
& \dot{m}_{\text {hot }}\left(h_{\text {hot, in }}-h_{\text {hot,out }}\right)=\dot{m}_{\text {cold }}\left(h_{\text {cold,out }}-h_{\text {cold, in }}\right) \\
& \Delta T_{\min }=\min \left[\left(T_{\text {hot, in }}-T_{\text {cold,out }}\right), \text { abs }\left(T_{\text {hot,out }}-T_{\text {cold, in }}\right)\right] .
\end{aligned}
$$

\section{Proposed Trigeneration System}

Figure 6 represents the system proposed here. MW is fed into a gasifier for the production of syngas via a two-step process. The first step involves the pyrolysis of the feedstock, whereas the second step utilizes a fixed bed gasifier. The pyrolyzed feedstock gasifies by steam and air mixture (gasification agents). A hot gas cleaner system (fuel conditioning system) is introduced, to remove the remaining contaminants present in the syngas such as sulfur, hydro chlorine, etc. The syngas temperature is well over $400^{\circ} \mathrm{C}(673 \mathrm{~K})$ and the partial pressure of steam is above 2 , which enables simpler designing of the gas cleaning system than for the cold gas cleaning system.

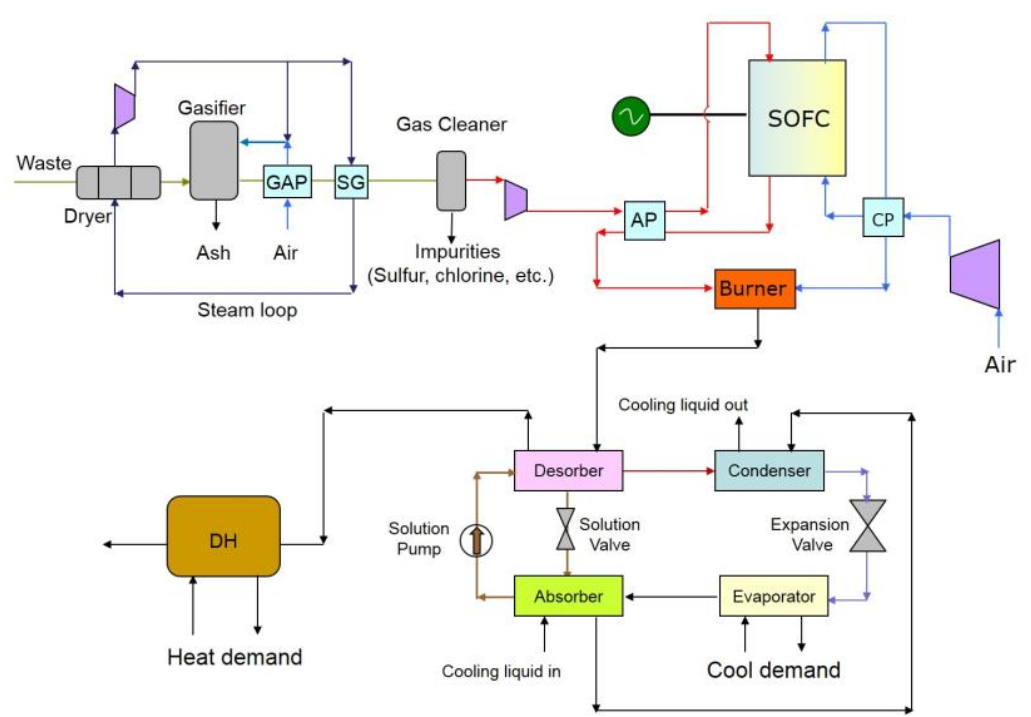

Figure 6: Representation of the integrated waste gasification with SOFC and Absorption Chiller system. $A P=$ anode preheater, $C P=$ cathode preheater, $D H=$ District Heating, GAP = gasifier air preheater, $S G=$ steam generator.

Owing to stringent environmental regulations in many industrial countries, the syngas cleaning systems are getting simpler than the exhaust cleaning system after combustion [42]. For small size plants, silicon carbide filters and/or electromagnetic filters would likely be sufficient for syngas 
particle purification. However, if the plant size is increased, then the fuel conditioning system may also contain cyclones and/or scrubbers prior to silicon-based filters (or electromagnetic filters). Depending on the origin/type of waste then catalytic cleaning system may also be required to decrease the sulfur and chlorine level to the acceptable levels, $1 \mathrm{ppm}$ respective $10 \mathrm{ppm}$. It is also worth noting that practical engineering may be more complicated than thermodynamic analyses. It is also assumed that by separating the gasifier into two steps then it would be possible to prolyze and gasify the waste that is well separated from metals, glasses, hard plastics, hard papers, etc. Such waste contains mainly waste foods, organics, some plastics, some papers, etc. Note that such cleaning system may take some of the energy and alter some results but this study does not consider such effect since the detailed cleaning system is missing.

A heat exchanger called for anode preheater (AP) preheats the cleaned syngas prior to the anode side of the fuel cell. Such preheating is essential to avoid fuel cell thermal fatigue, e.g. $130^{\circ} \mathrm{C}(403$ $\mathrm{K})$ for about $10-15 \mathrm{~cm}$ long cell, which has a thickness in $\mu \mathrm{m}$.

On the cathode side, air is first compressed and then preheated in the cathode preheater $(\mathrm{CP})$ before entering the fuel cell. Again, such air preheating is vital to evade cell thermal tensions, e.g. $180^{\circ} \mathrm{C}$ ( $453 \mathrm{~K}$ ) for about $10-15 \mathrm{~cm}$ long and 10-20 $\mu \mathrm{m}$ thick cell. The operating temperature of the fuel cell is assumed to be $780^{\circ} \mathrm{C}(1053 \mathrm{~K})$, which is also used to preheat the both the incoming syngas as well as incoming air. A burner is used to burn the unused fuel out of the anode side of the fuel cell. The burner is required because all of the fuel does not react in the fuel cell stacks, owing to incomplete fuel utilization. A heat exchanger (Heat Recovery) recovers heat for both domestic hot water consumption and space heating. Table 5 presents system-operating parameter assumed in this study.

As described above, the absorption mixes a rich refrigerant solution with a weak solution (refrigerant) and then a pump send this mixture to the generator (known as desorber). The desorber receives the waste heat (from the SOFC plant) and as a result, the refrigerant converts into a gaseous phase, separates the refrigerant from the liquid solution and heads the weak solution to a condenser while the rich solution goes back to the absorber after passing a solution valve. In the condenser, the weak solution transforms into liquid by rejecting heat to a heat sink (condenser), which is either air or water but with lower inlet temperature (represented as cooling liquid in the Fig. 6). The liquid refrigerant now passes through an expansion valve where its pressure decreases (as well as its temperature) before continuing to an evaporator. In the evaporator, it absorbs heat from a higher temperature source, which in fact is the cooling demand. The refrigerant vapor then mixes with the liquid solution (coming from the other outlet of the desorber) in the absorber to form a rich liquid solution. A pump send this mixture back to the desorber and the cycle is then closed.

Table 5: System operating input parameters.

\begin{tabular}{c|c}
\hline Parameter & Value \\
\hline MW mass flow $(\mathrm{kg} / \mathrm{h})$ & 105.3 \\
MW temperature $\left({ }^{\circ} \mathrm{C}\right)$ & 15 \\
Drying temperature $\left({ }^{\circ} \mathrm{C}\right)$ & 150 \\
Gasifier outlet temperature $\left({ }^{\circ} \mathrm{C}\right)$ & 800 \\
Gasifier pressure $($ bar $)$ & 1 \\
Gasifier pressure drop $($ bar $)$ & 0.005 \\
Gasifier carbon conversion factor & 1 \\
Gasifier non-equilibrium methane & 0.01 \\
Steam blower isentropic efficiency & 0.8 \\
Steam blower mechanical efficiency & 0.98 \\
Air temperature into gasifier $\left({ }^{\circ} \mathrm{C}\right)$ & 15 \\
Syngas blower isentropic efficiency & 0.7 \\
Syngas blower mechanical efficiency & 0.95 \\
Syngas cleaner pressure drop & 0.0049 \\
Blower air intake temperature $\left({ }^{\circ} \mathrm{C}\right)$ & 15 \\
Blower isentropic efficiency & 0.7
\end{tabular}




\begin{tabular}{c|c} 
Blower mechanical efficiency & 0.95 \\
Gas heat exchangers pressure drop (bar) & 0.01 \\
Cathode preheater pressure drop (bar) & 0.04 \\
Anode preheater pressure drop (bar) & 0.01 \\
Burner inlet-outlet pressure ratio & 0.95
\end{tabular}

The outlet temperature of the gasifier is assumed to be $800^{\circ} \mathrm{C}(1073 \mathrm{~K})$ while the temperature inside the gasifier is much higher, about $1300^{\circ} \mathrm{C}(1573 \mathrm{~K})$. The pressure drops assumed in the table are the results of calculating the Re-number and then friction factor in ducts. The blower (compressor) isentropic and mechanical efficiency are taken from real ones. The same is true for the steam generator. The SOFC stacks are not pressurized and they are working slightly above the ambient pressure. The bowers provide the pressure to overcome the pressure drops of the components along their pathways (both air and fuel blowers).

Finally, it is also important to note that the realizability of such plant depends entirely on the technique of waste gasification and production of syngas suitable to feed the SOFC plant. Wärtslä Corporation has already built two SOFC plant fueled by methanol and landfill gas, one as auxiliary unit in a ship and one as small power generator [43]. There are also some small SOFC units in the market for household applications. The absorption chillers exist as commercial units in the market. Thus, the realization of SOFC combined with AC should technically be possible, if one neglect the associated cost. However, the gasification of municipal waste (after basic recycling techniques) to produce a syngas suitable to feed SOFC is challenging and some technical problems must be solved, before integrating it with the combined SOFC-AC plant.

\section{Results and discussions}

The first parameters to be studied are municipal waste moisture content and its mass flow, see Fig. 7a. These parameters may vary time to time and therefore their effect on plant performance in terms of plant power, heat and cool production shall be studied. As seen waste moisture has a positive effect on the plant efficiency, increasing moisture increases plant efficiency slightly $(0.2 \%$ only). However, net power as well as cooling and heating effects decreases when moisture content is increased. Cooing, heating and net power decreases by $26.5 \%, 23.3 \%$ and $24.3 \%$ respectively which are significant. Variation of waste mass flow and its effect on plant power production is shown in Fig. 7b. As expected, plant cooling and heating effect as well as net power increases with waste mass flow. However, plant efficiency decreases with increasing waste mass flow. The reason is that number of stack is specified and when more fuel is fed to the stacks, then the current density increases and thereby polarization losses increases which is also dominating in this region.

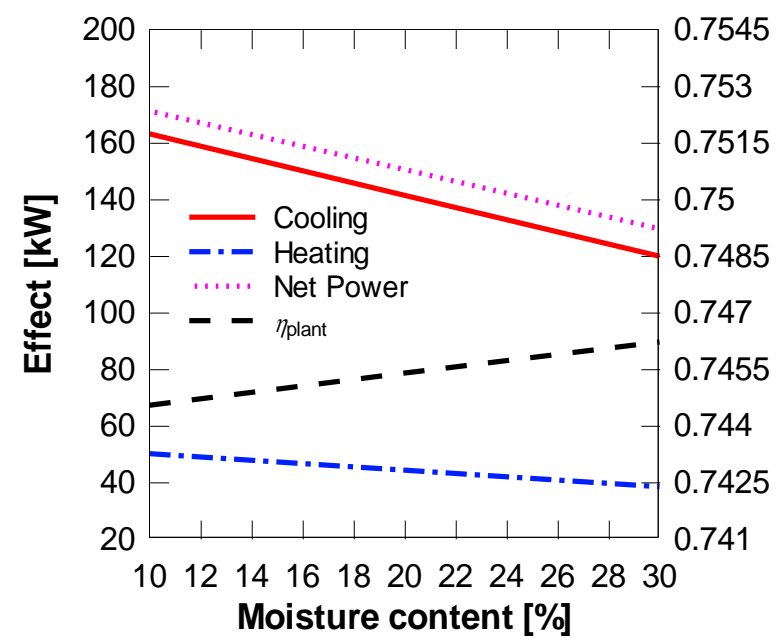

(a)

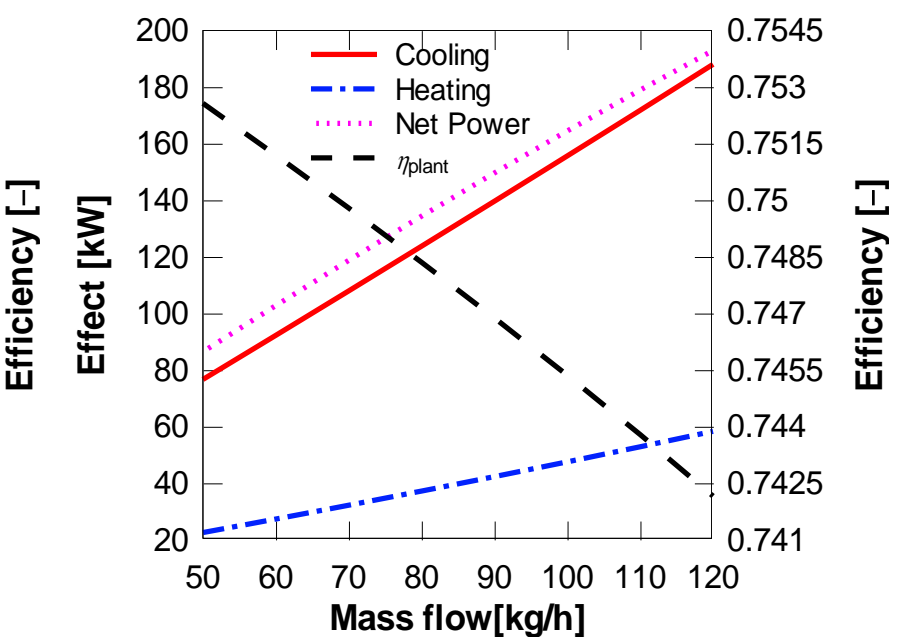

(b)

Figure 7: Plant performance as function of waste moisture content (a) and waste mass flow (b). 
Other interesting parameters to be studied are SOFC operating temperature and its utilization factor, which are shown in Fig. 8. As presented in Fig. 8a there exist an optimum SOFC operating temperature $\left(690^{\circ} \mathrm{C}, 963 \mathrm{~K}\right)$ at which plant efficiency is maxima for utilization factor of $67.5 \%$ (base case). Above this temperature plant efficiency decreases and thereby fuel cell net power decreases as well. This in turn leaves more heat to be available for heating and cooling devices and therefore their production will increase as a result. Similarly, below this optimum temperature plant efficiency as well as fuel cell net power decreases leaving more heat for the heating and cooling devices and thereby their effect increases.

Fig. 8b displays SOFC utilization factor versus plant efficiency and produced trigeneration effect. It is also shown that for utilization factor of $70 \%$, plant efficiency and plant net power becomes maximum (optimum point). However, with increasing utilization factor, the plant heating effect increases while the plant cooling effect decreases until a certain point at which suddenly cell voltage decreases significantly because of cell polarization losses (after about 77\%). Due to sudden decrease in fuel cell power, heat available for heating and cooling devices increases and thereby produced heating and cooling effects increases suddenly as the consequence.

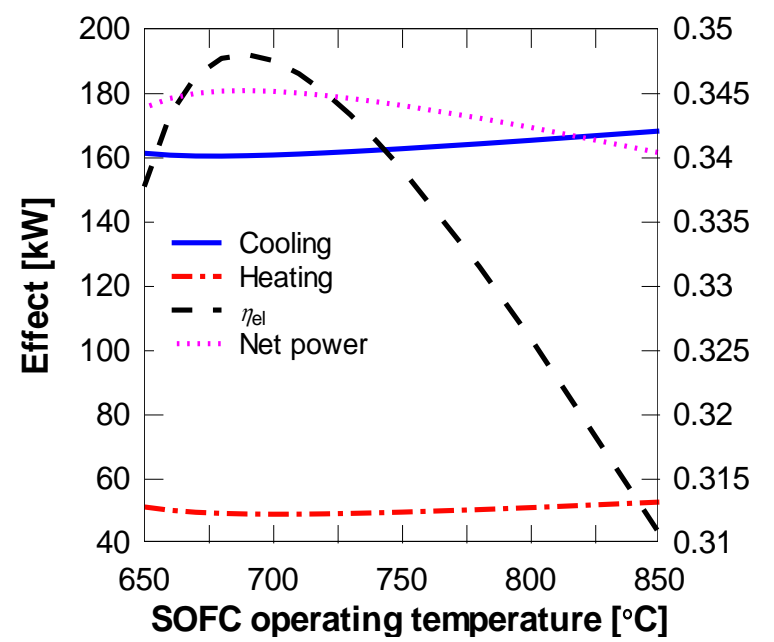

(a)

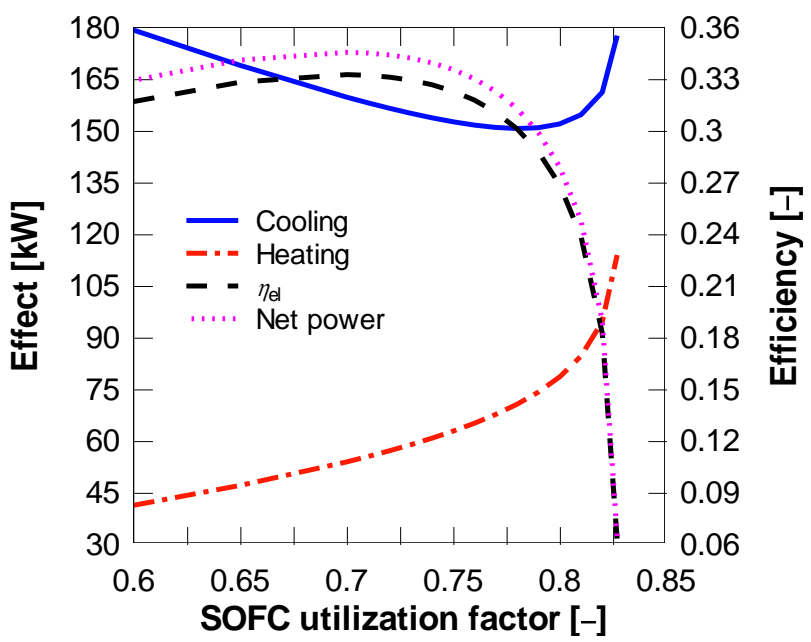

(b)

Figure 8: Plant performance as function of SOFC operating temperature (a) and SOFC utilization factor $(b)$.

It is worth to mention that the obtained results are valid when other parameters remains unchanged such as number of stack (160), fuel mass flow $(105 \mathrm{~kg} / \mathrm{h})$ and either SOFC operating temperature or its utilization factor. Changing these parameters from the base case alters the obtained results here, and other values may be attained. For example, the optimum SOFC operating temperature will change when fuel mass flow and number of stack changes.

\subsection{Effect of Desorber Outlet Temperature}

Another parameter to be investigated is the desorber outlet temperature, which is assumed to be $135^{\circ} \mathrm{C}(408 \mathrm{~K})$ in the base case. However, this value is rather high for such plant since off-gases are rather clean after the cleaning system and therefore surface oxidation shall be neglected and the attention can be paid on the dewpoint only (avoiding condensation). The dewpoint of such gases is assumed approximately $70^{\circ} \mathrm{C}(353 \mathrm{~K})$, when leaving the heat exchanger for heat production. Thus, the temperature out of the desorber shall be slightly higher.

Decreasing the desorber outlet temperature would be in favor of cooling effect as presented in Fig. 9, while it has a negative impact on heat production. For example, decreasing desorber outlet temperature from $135^{\circ} \mathrm{C}(408 \mathrm{~K})$ to $90^{\circ} \mathrm{C}(363 \mathrm{~K})$ increases cooling effect by $11.5 \%$ while heat production decreases by $66.8 \%$. Note that the plant net power as well as its thermal efficiency does 
not change when varying desorber outlet temperature. In practical design, the plant functionality in terms of heating and cooling effect can be controlled via the mass flow of the off gases passing through the desorber (or a temperature sensor). The figure also displays that plant fuel utilization $(\varepsilon$, total efficiency) increases slightly, from about 0.71 to about 0.76 when desorber temperature changes from $80^{\circ} \mathrm{C}(353 \mathrm{~K})$ to $160^{\circ} \mathrm{C}(433 \mathrm{~K})$.

It shall be noted that the mass flow of the water (other side of the heat recovery heat exchanger) is assumed to be $0.1 \mathrm{~kg} / \mathrm{s}$, although any other values could be assumed since its value does not alter the results obtained here.

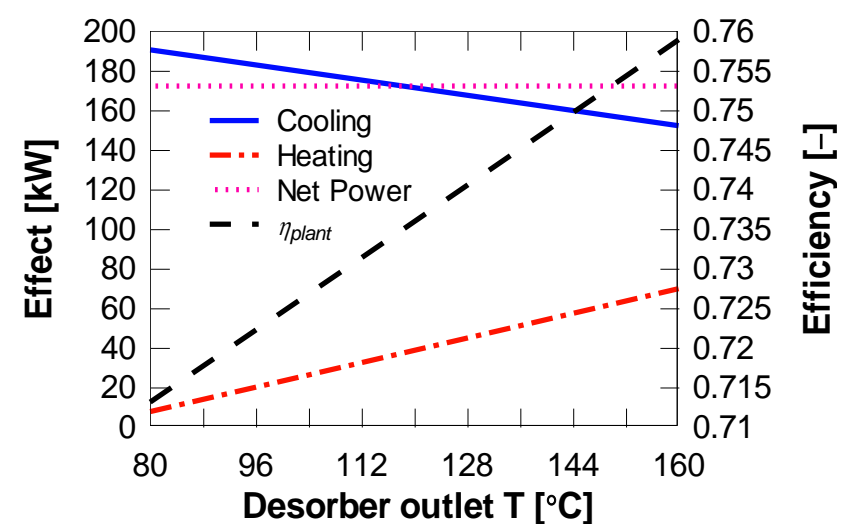

Figure 9: Plant performance as function of desorber outlet temperature.

\subsection{Effect of Weak Solution and Rich Solution}

The weak and rich solutions in the base case were assumed to be 0.548 and 0.593 respectively. Changing these values will effect on the amount of cooling production as well as heating production, which is investigated in Fig. 10. The figure shows that decreasing the weak solution (while the reach solution is kept constant) as well as increasing the rich solution (while the weak solution is kept constant) increases the cooling effect. The reason is that the difference between the rich and weak solution increases. Note that based on the serial design of district cooling and district heating, the amount of heating production will not change. Since only the amount of cooling production will alter then it means that the COP of the absorption chiller will change. As mentioned above, the COP of the absorptions chillers are rather small and usually lie between 0.5 and 0.9 , which is also justified in Fig. 10. COP increases by decreasing the weak solution (Fig. 10a) and increasing the rich solution (Fig. 10b). The value for COP strongly depends on the difference between the rich and weak solutions and it is obvious that the COP can change if the difference between the rich and weak solutions increases. To reach a value close to unity, demands technical refinement and component improvement, which is out of the scope of this study.

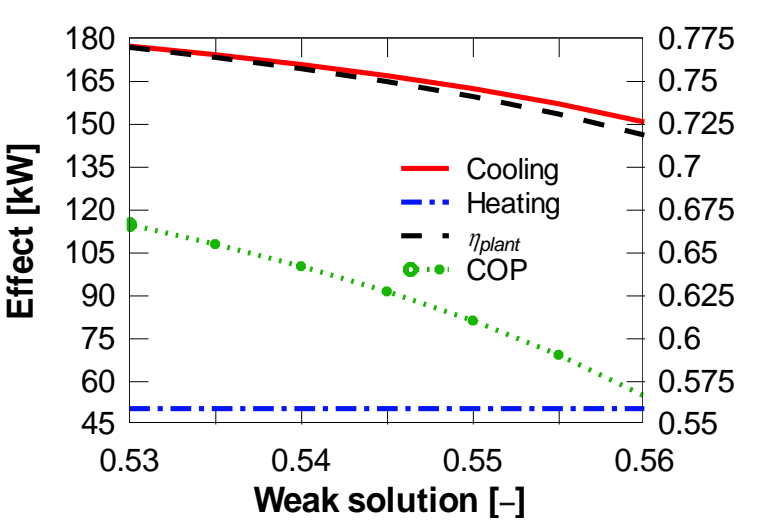

(a)

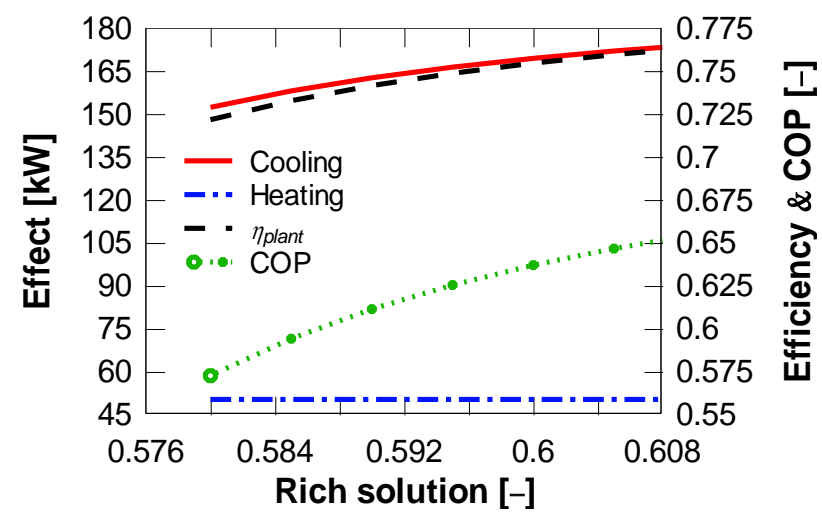

(b)

Figure 10: Effect of weak and rich solution on cooling and heating. 
Note that, the condensing temperature limits the high-pressure level in the system, so that to ensure the entire vapor refrigerant condenses. By increasing the pressure in the condenser, heat should be rejected at a lower temperature for the condensation to take place. The present study assumes that the pressure in the condenser is 16 bar as stated previously. Furthermore, the available cooling in the absorber will set the limit for the concentration of refrigerant (water) which the LiBr can absorb. The higher the refrigerant concentration the lower the temperature in the absorber should be. Crystallization risk defines the lower limit for of refrigerant in the rich $\mathrm{Li}$-Br concentration connection see [44] and [45]. The range studied here is far from the crystallization becomes an issue (calculated as $1-0.608=0.392$ ).

In the base case the difference between the rich and weak solutions (denoted as $\mathrm{X}$ in the Fig. 11) assumed to be 0.044 . Increasing this difference to 0.2 then the cooling production will also increase as denoted in Fig. 11. The cooling effect increases from about $170 \mathrm{~kW}$ (Fig. 11a) to about $200 \mathrm{~kW}$ (Fig. 11b) and at the same time, plant energy efficiency increases from about 0.75 (Fig. 11a) to about 0.82 (Fig. 11b). Meanwhile COP will also increase from about 0.62 (Fig. 11a) to about 0.77 (Fig. $11 b)$.

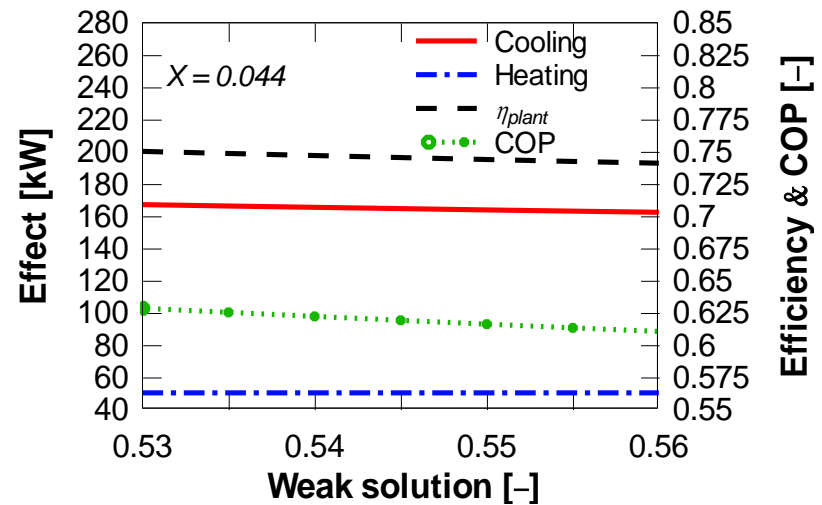

(a)

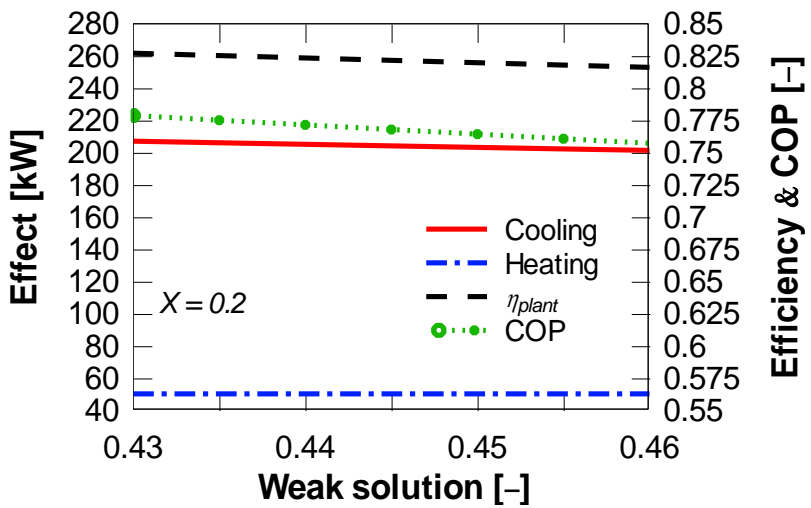

(b)

Figure 11: Effect of the difference between the rich and the weak solution $(X)$ on plant cooling and heating, a) $X=0.044$ and $b$ ) $X=0.2$

Figure 12 displays the difference between rich and solution for some selected values. As seen in the figure, COP deceases when the value for the weak solution increases. Therefore, one should select a low value for the weak solution when optimizing the absorption chiller, which acts as bottoming cycle for the SOFC plant. Another important conclusion from Fig. 12 is that when the difference between rich and weak solution is about 0.15 then COP maximizes (Fig. 12a). In other words, COP increases when such difference increases from 0.1 to 0.15 and starts to decrease when such difference is above 0.2 . Figure $12 \mathrm{~b}$ examines the small difference with the range of 0.14 to 0.16 from which one can conclude the optimum value is about 0.15 .

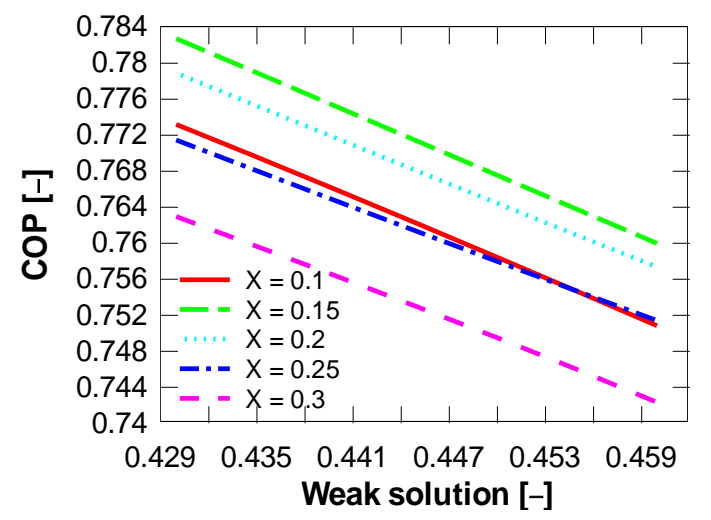

(a)

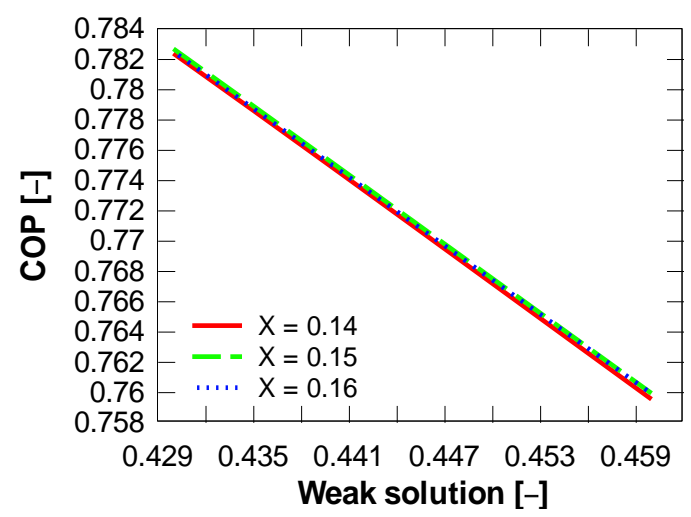

(b) 
Figure 12: COP as function of difference between rich and weak solution for some selected values. ( $X=$ the difference between rich and weak solution)

\subsection{Flue Gas Condensation}

The most effective way to recover energy from the flue gas, and in many cases also an economically interesting technology, is flue gas condensation. In addition to the high-energy recovery potential of this process, dust precipitation efficiencies of 40-75 percent is achievable. Furthermore, there is the possibility of preventing condensation of the flue gas in the chimney down to ambient temperatures of about $-10^{\circ} \mathrm{C}$ [46]. The amount of energy that to be recovered from the flue gas depends on the moisture content of the fuel, the amount of excess oxygen in the flue gas and the temperature of the cooling water. The latter is the temperature of the return water from the district (or domestic) heating network in this study. The lower the temperature of the return water, the higher the amount of latent heat that can be recovered, when the flue gas is cooled below the dew point. This is main the reason why the temperature levels for district heating in this study is based on a $4^{\text {th }}$ generation district hating, as shown in Fig. 13. The pinch temperature used in this study is 5 degrees.

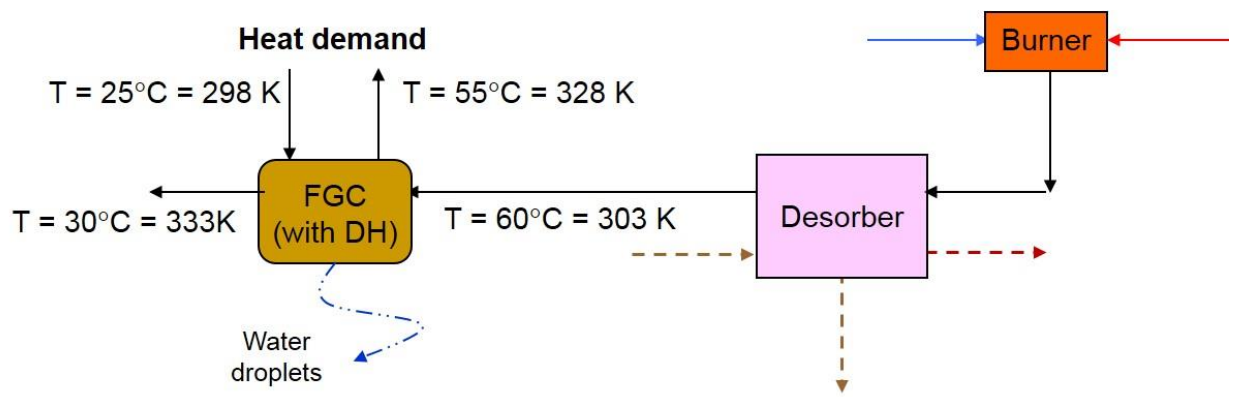

Figure 13: Temperatures in the flue gas condensation (FGC) according to the 4th generation DH (district Heating) for series connection with bottoming cycle.

As mentioned above, the flue gases after the desorber is cooled down is assumed to be $135^{\circ} \mathrm{C}(408$ $\mathrm{K}$ ), allowing some heat to be available for the district heating. However, it is possible to combine a Flue Gas Condensation (FGC) in combination with the desorber and therefore allowing the flue gases to be further cooled down below the dew point to produce additional cooling in expense of heating. Such solutions may allow to vary the cooling effect during warm days. In this study, the flue gases are cooled down to $30^{\circ} \mathrm{C}$. Figure 14 demonstrates the results of such investigation.

As seen in Fig. 14, decreasing the flue gases temperature from $135^{\circ} \mathrm{C}$ to $60^{\circ} \mathrm{C}$ increases the cooling from about $164 \mathrm{~kW}$ to about 200kW while the heating decreases from about $86 \mathrm{~kW}$ to about $28 \mathrm{~kW}$. The plant efficiency decreases slightly, from $81 \%$ to $77 \%$, since the COP of the absorption chiller is less than the effectiveness of the heat exchanger for district heating (and FGC). It is obvious that the $\mathrm{COP}$ of the absorption chiller does not change since its design and parameters do changed compared to the base case mentioned above. 


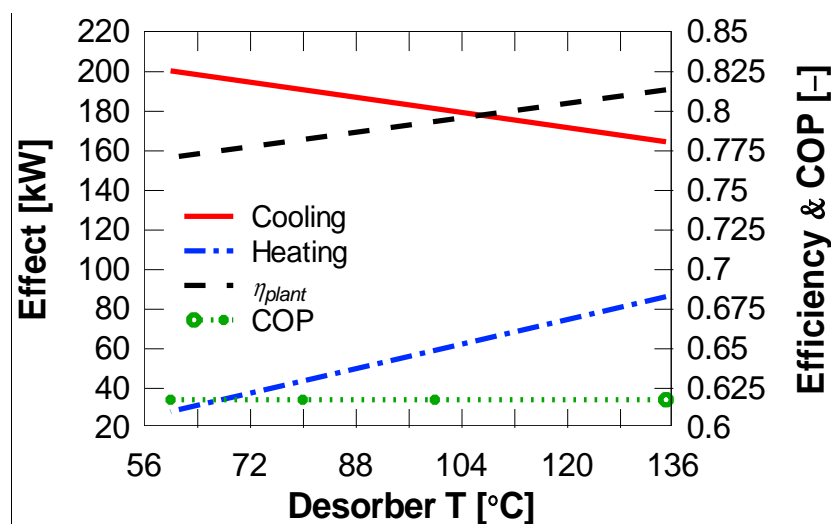

Figure 14: Effect of flue gas temperature on produced cooling and heating.

\subsection{Optimized plant}

Bases on the studies above one can find the optimum case based on SOFC utilization factor and the difference between rich and weak solution as specified in Table 6. As seen the topping cycle (SOFC plant) performance does not changes significantly since the SOFC utilization factor for the optimum case is very close to the corresponding value for the basic case (compare 0.7 with 0.675 respectively). However, the performance of the bottoming cycle (absorption chiller) changes significantly from the basic case to the optimum case. The reasons are; a) the weak solution for the optimum case is lower than corresponding value for the basic case, and b) the difference between rich and weak solution for the optimum case is larger than corresponding value for the basic case. In the table, district energy (DE) defines the summation of district cooling and district heating.

The cooling effects increases by about $23 \%$ (from about $164 \mathrm{~kW}$ to about $203 \mathrm{~kW}$ ), which is substantial thanks to new values for weak and rich solutions. Meantime the heating effect increases by about $7 \%$, which is mainly due to the increase in compressor flow. The compressor flow in the optimum case increases slightly to cool down the fuel cells at the desired temperature (here $780^{\circ} \mathrm{C}$ or $1053 \mathrm{~K}$ ), as extensively discussed by the author in previous publications.

Table 6: Comparison between optimum and basic cases.

\begin{tabular}{l|c|c|c}
\hline \multicolumn{1}{c|}{ Parameter } & Basic & Optimized & $\begin{array}{c}\text { Optimized } \\
\text { with FGC }\end{array}$ \\
\hline SOFC utilization factor (-) & 0.675 & 0.700 & 0.700 \\
Net power (kW) & 172.20 & 172.75 & 172.65 \\
Electric efficiency (\%) & 33.2 & 33.3 & 33.2 \\
Weak solution (-) & 0.548 & 0.430 & 0.430 \\
Rich solution (-) & 0.592 & 0.580 & 0.580 \\
District cooling (kW) & 164.19 & 202.51 & 251.25 \\
District heating (kW) & 50.34 & 53.92 & 26.88 \\
District energy (kW) & 214.53 & 256.43 & 278.12 \\
COP of absorption chiller (-) & 0.635 & 0.783 & 0.783 \\
Plant energy efficiency, $\eta_{\text {plant }}(\%)$ & 74.5 & 82.6 & 86.8 \\
\hline
\end{tabular}

Table 6 also demonstrates the effect of FGC on plant performance. The cooling effect increases by $53 \%$ while the heating effect decreases by about $47 \%$. As demonstrated, the FGC increases the cooling effect on the expense of heating. However, DE (summation of cooling and heating) increases by about $30 \%$, which is significantly higher when compared to the base case. Further, the plant energy efficiency increases by 12.3 point-percent, which is a noteworthy value (from $74.5 \%$ to $86.8 \%$ ).

\subsection{Various Different Wastes}


Due to the heterogeneous nature of MW, the characteristics will vary depending on numerous factors, such as geographical region, income level, culture and so forth. The previously mentioned report from the World Bank shows a significant difference in waste fractions depending on income level, as shown in [47]. The variation in fractions results in different chemical compositions and thermodynamic properties and therefore it would be interesting to study the effect of waste compositions on plant performances. Determining an average chemical composition and heating value applicable for MW worldwide is in essence impossible and therefore the present study focuses primarily on Denmark and Danish produced waste which is categorized in detail. Based on the study of [20], it is possible to categorize the Danish as shown in Table 7. The table clearly shows that the compositions as well as HHV (Higher Heating Values) varies widely depending on the source of waste, such as in homes (DK 1 and DK 2), health care services, hotels and department stores.

The first column is the Danish household waste from 2015, denoted as DK 1while the second is the Danish household data from 2009, denoted as DK 2. The third column is the waste from health care services (DK Health), such as a hospital and is based on the fractions collected by [48] and adapted as best possible to waste fractions in [49]. The remaining two columns are the hotel and restaurant industry (DK Hotels) and shopping centers or department stores (DK Stores).

As expected, the two household wastes are very similar in fractions and element composition, despite the year differences between the analyses. The health services waste contains a huge amount of paper and board, lowering the moisture significant. This is most likely due to the massive amount of sterilized equipment in packaging and other disposable material such as paper towels, etc. The waste from shopping centers follow a similar trend and because of high amounts of paper, board, and low food waste fraction, the moisture contents are almost half when compares to households.

Tabel 7: Different waste compositions used in this study.

\begin{tabular}{c|c|c|c|c|c}
\hline Compound & DK 1 & DK 2 & DK Health & DK Hotels & DK Stores \\
\hline $\mathrm{C}(\%)$ & 49.92 & 47.72 & 46.92 & 42.21 & 45.39 \\
$\mathrm{H}(\%)$ & 6.90 & 6.51 & 6.41 & 5.86 & 6.21 \\
$\mathrm{O}(\%)$ & 23.49 & 24.77 & 28.65 & 23.82 & 26.56 \\
$\mathrm{~S}(\%)$ & 0.21 & 0.20 & 0.15 & 0.16 & 0.16 \\
$\mathrm{~N}(\%)$ & 2.51 & 2.34 & 1.11 & 2.28 & 1.42 \\
$\mathrm{Ash}(\%)$ & 16.91 & 18.95 & 16.77 & 25.68 & 20.26 \\
$\mathrm{HHV}(\mathrm{kJ} / \mathrm{kg})$ & 22750 & 21180 & 20610 & 18610 & 19990 \\
$c_{p}(\mathrm{~kJ} / \mathrm{kg})$ & 1.90 & 1.87 & 1.83 & 1.85 & 1.84 \\
Moisture & 33.81 & 33.23 & 12.40 & 34.40 & 18.12 \\
\hline
\end{tabular}

Using the optimized weak and rich solutions discussed in the previous subsection, Fig. 15 shows the calculation results for these different Danish wastes. In order to have a fair comparison the mass flow of the waste as well as all other parameters did not change when simulating with different wastes. It means that once the system is designed then it is fed with different fuels under same condition and the same fuel mass flow. Thus, the obtained results gives a perspective on the quality of waste when the system is fed with different wastes.

As displayed in Fig. 15, the waste from heath care services provides the highest cooling, heating and net power effect followed by waste from the shopping centers. The waste from hotels and restaurants gives the lowest cooling, eating and net power effects. The cooling effect from health care services reaches to about $196 \mathrm{~kW}$ while the waste from hotels and restaurants provides only $126 \mathrm{~kW}$, with other words $36 \%$ less effect. Similarly, the heating effect and net power from heath care services are higher than for the hotels $(10 \%$ vs. $8 \%)$. The effects obtained from the household wastes at different years (2015 and 2009) are almost similar with small differences. Despite similar values in HHV (Higher Heating Values), the district energy (cooling plus heating) as well as net power for the health care case is much higher than the case for department stores. Compare $245.2 \mathrm{~kJ} / \mathrm{Kg}$ with 220.3 $\mathrm{kJ} / \mathrm{Kg}$ for district heating (from heath care services) and $159.2 \mathrm{~kW}$ for net power with $146.1 \mathrm{~kW}$ for 
net power (from department stores/shopping centers). These results are very interesting and clearly demonstrate that different wastes gives different results depending on the source of the waste.

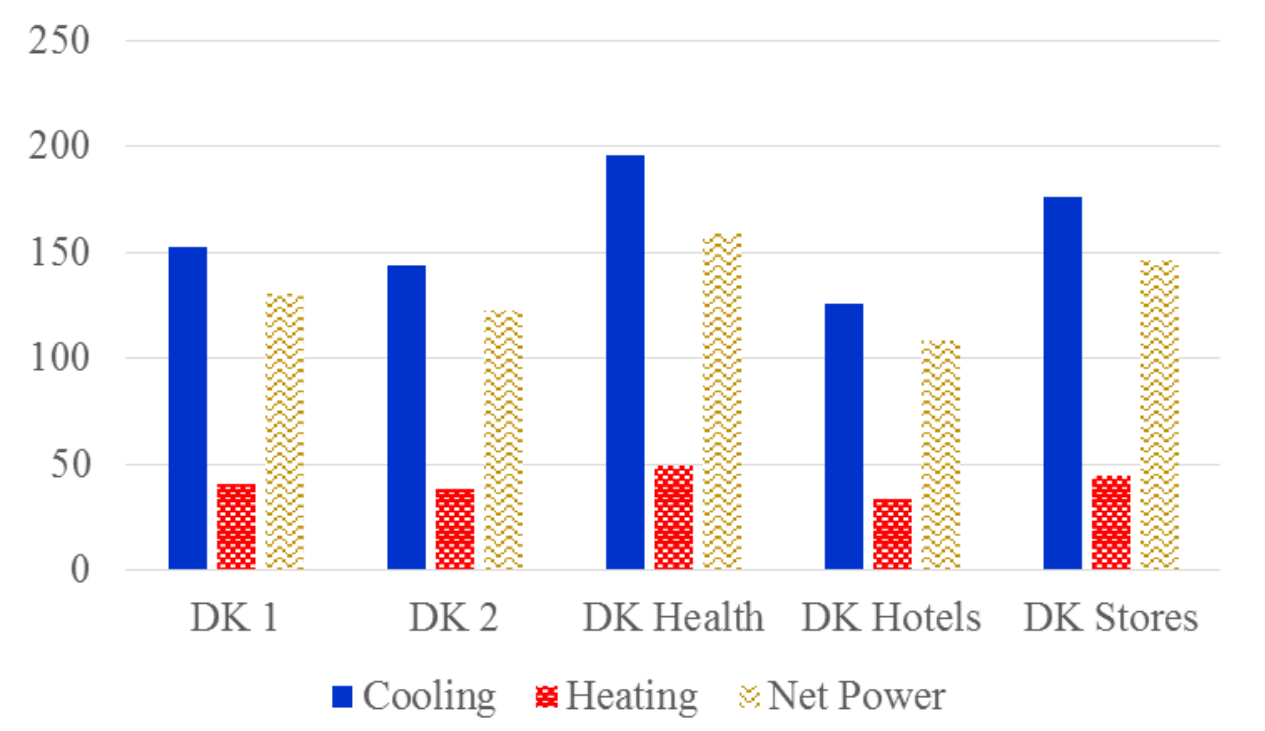

Figure 15: Cooling, heating and net power production as function of various wastes.

The efficiencies (both electric and energy) show a surprising result as displayed in Fig 16. The efficiency is highest for least expected fuel namely hotel and restaurant business. This fuel has the highest content of moisture and thereby lowest heating value. Despite this fact, it performs better than other fuels. The reason is that, the number of fuel cell stacks are too few for this particular fuel. On the other hand, one cannot change number of stacks once the plant is built, but the type of the fuel may change. The energetic efficiency for waste from hotels reaches to $86.2 \%$ while it remains at about 83 to $84 \%$ for all other fuels. Corresponding electric efficiency for the plant fed by waste from hotels is $35 \%$, which is 2.1 point-percent high than the case with health care.

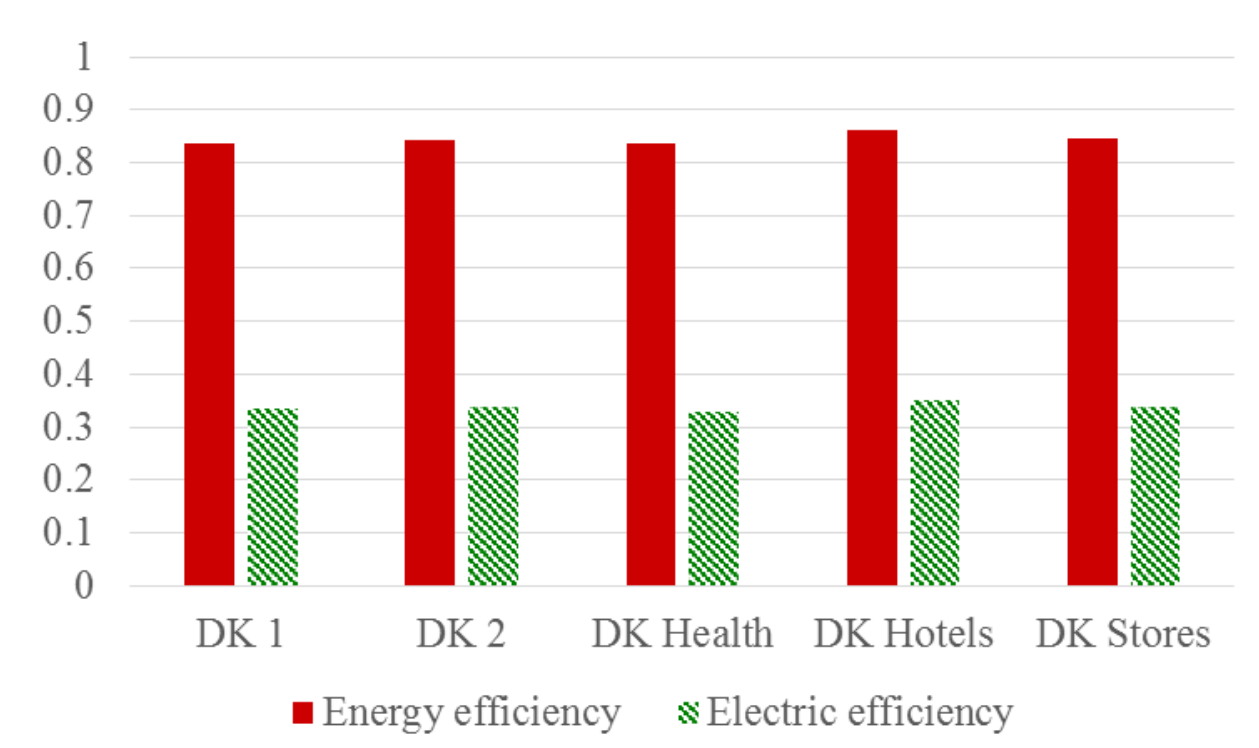

Figure 16: Energy efficiency, electric efficiency and COP as function of various wastes.

Table 8 summarizes the results discussed above and presented in Figs. 15 and 16. Further, as seen from Table 8 the COP of the absorption chiller does not changes when feeding fuel changes. The reason is obvious and it is because that the absorption plant does not change for different fuels. It is a standalone plant and works as bottoming cycle for the SOFC plant by utilizing the waste heat from the topping cycle. 
Table 8: Plant performances for different Danish waste compositions.

\begin{tabular}{c|c|c|c|c|c}
\hline & DK 1 & DK 2 & DK Health & DK Hotels & DK Stores \\
\hline Cooling $[\mathrm{kW}]$ & 152.84 & 143.98 & 195.92 & 125.62 & 175.80 \\
Heating [kW] & 40.40 & 37.92 & 49.30 & 33.14 & 44.49 \\
Net power [kW] & 130.08 & 122.77 & 159.18 & 108.74 & 146.13 \\
Electric efficiency (\%) & 33.59 & 33.90 & 32.93 & 35.05 & 33.72 \\
Plant efficiency (\%) & 83.50 & 84.12 & 83.66 & 86.21 & 84.56 \\
COP [-] & 0.783 & 0.783 & 0.783 & 0.783 & 0.783 \\
\hline
\end{tabular}

\section{Conclusions}

A trigeneration system based on municipal waste, solid oxide fuel cell and abruption chiller is presented and thermodynamically analyzed. This study presents also a design on detailed balance of plant under consideration. The investigations shows that plant electrical efficiency increases by increasing fuel moisture content under specified waste mass flow and specified number of fuel cell stacks.

It is also revealed that for the specified waste composition and number of cells, the optimum SOFC utilization factor is $70 \%$ and plant electric efficiency decreases significantly if utilization is beyond about $77 \%$ (mainly due to increase in concentration losses).

Fuel utilization (energy efficiency) beyond 0.76 is easily achievable by such trigeneration system when heating effect, cooling effect and net power are included for such system.

Producing more heat results in improved plant energy efficiency (total efficiency) in expense of lower cooling effect. Other conclusions among many are that increasing waste mass flow is in favor of electricity, heat and cool production, while increasing waste moisture content decreases them.

Different types of Danish wastes were also considered to study their effect of plant performances. For example, it is shown that under similar plant design and fuel mass flow, the waste from heath care services provides highest energy (cooling and heating) and net power while plant energetic efficiency is higher for case with waste from hotels and restaurants industries.

\section{Nomenclature}

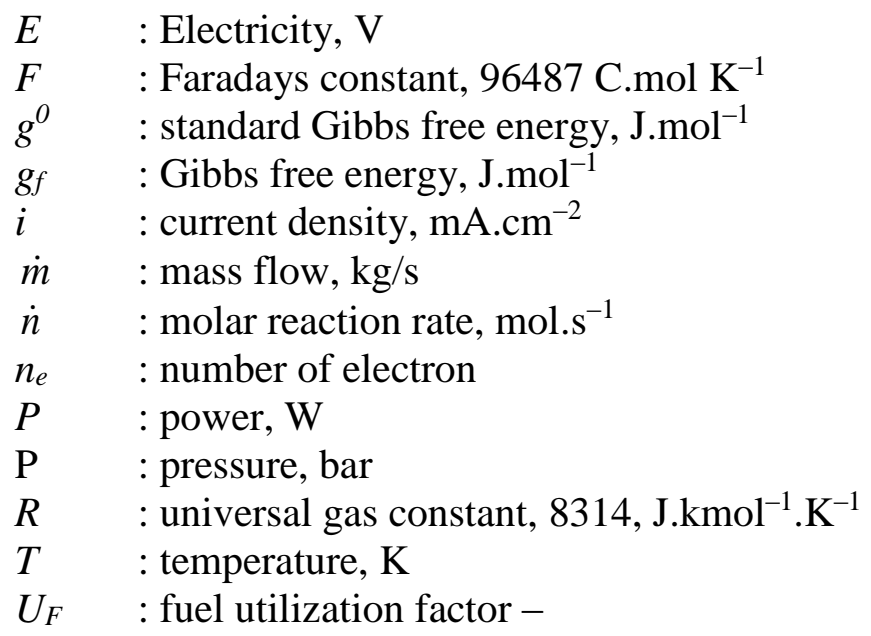

\section{Greek Letters}

$\Delta \quad:$ difference, -

$\eta \quad:$ efficiency, -

$\rho \quad$ : density, $\mathrm{kg} / \mathrm{m} 3$

$h \quad$ : enthalpy, $k J / k g$ 
Subscripts

ohm : ohmic

conc : concentration

inv : inventor

rev : reversible

$\mathrm{v}$ : voltage

Abbreviations

AP : Anode Preheater

AC : Absorption Chiller

CP : Cathode Preheater

COP : Coefficient of Performance

DE : District Energy

FGC : Flue Gas Condensation

GAP : Gasifier Air Preheater

HHV : Higher Heating Value

LHV : Lower Heating Value

MW : Municipal Waste

SG : Steam generator

SOFC : Solid Oxide Fuel Cell

\section{References}

[1] Sanchez D, Chacartegui R, Torres M and Sanchez T. Stirling based fuel cell hybrid systems: an alternative for molten carbonate fuel cells. Power Sources 2008;192:84-93.

[2] Rokni M. Thermodynamic analysis of SOFC (solid oxide fuel cell) - Stirling hybrid plants using alternative fuels. Energy 2013;61:87-97.

[3] Lee KH and Strand RK. SOFC cogeneration system for building applications, part 2: System configuration and operating condition design. Renewable Energy 2009;34(12):2839-46.

[4] Niessen WR, 2010. Combustion and Incineration Processes: Applications in Environmental Engineering, fourth ed. CRC Press, Massachusetts, USA.

[5] Riensche E, Achenbach E, Froning D, Haines MR, Heidug WK, Lokurlu A and Adrian S. Clean combined-cycle SOFC power plant-cell modeling and process analysis. Power Sources 2000;86(12):404-10.

[6] Rokni M. Plant characteristics of an integrated solid oxide fuel cell cycle and a steam cycle. Energy 2010;35:4691-99.

[7] Weber C, Koyama $\mathrm{M}$ and Kraines S. CO2-emissions reduction potential and costs of a decentralized energy system for providing electricity, cooling and heating in an office-building in Tokyo. Energy 2006;31:3041-3061.

[8] Chen JMP and Ni M. Economic analysis of a solid oxide fuel cell cogeneration/trigeneration system for hotels in Hong Kong. Energy and Buildings 2014;75:160-169.

[9] Baniasadi E, Alemrajabi AA. Fuel cell energy generation and recovery cycle analysis for residential application. Hydrogen Energy 2010;35:9460-9467. 
[10] Yu Z, Han J, Cao X, Chen W, Zhang B. Analysis of total energy system based on solid oxide fuel cell for combined cooling and power applications. Hydrogen Energy 2010;35:2703-2707.

[11] Ozcan H, Dincer I. Thermodynamic Analysis of an Integrated SOFC, Solar ORC and Absorption Chiller for Tri-generation Application. Fuel Cells 2013;13(5):781-793.

[12] Shariatzadeh OJ, Refahi AH, Rahmani M, Abolhassani SS. Economic optimisation and thermodynamic modelling of SOFC tri-generation system fed by biogas. Energy Conversion and Management 2015;105:772-781.

[13] Bompard E, Napoli R, Wan B and Orsello G. Economics evaluation of a 5kW SOFC power system for residential use. Hydrogen Energy 2008;33:3243-47.

[14] Farhad S, Hamdullahpur F and Yoo Y. Performance evaluation of different configurations of biogas-fuelled SOFC micro-CHP systems for residential applications. Hydrogen Energy 2010;35:3758-68.

[15] Liso V, Brandon N, Zhao Y, Nielsen MP and Koer SK. Analysis of the impact of heat-to-power ratio for a SOFC-based mCHP system for residential application under different climate regions in Europe. Hydrogen Energy 2011;36:13715-26.

[16] Lamas J, Shimizu H, Matsumura E and Senda J. Fuel consumption analysis of a residential cogeneration system using a solid oxide fuel cell with regulation of heat to power ratio. Hydrogen Energy 2013;38:16338-43.

[17] Hebenstreit B, Schnetzinger R, Ohnmacht R, Hoeftberger E, Lundgren J, Haslinger W and Toffolo A. Techno-economic study of a heat pump enhanced flue gas heat recovery for biomass boilers. Biomass and Bioenergy 2014;71:12-22.

[18] Elmegaard B, Houbak N. DNA - A general energy system simulation tool. Proceeding of SIMS 2005, Trondheim, Norway. Eds: Amundsen J, Andersson HI, Celledoni E, Gravdahl T, Michelsen FA, Nagel HR and Natvig T. Oct 13 - 14, 2005. ISBN: 9781617388729 . Pages $43-52$.

[19] Meraz L, Domínguez M, Kornhauser I, and Rojas F. A thermochemical concept-based equation to estimate waste combustion enthalpy from elemental composition. Fuel 2003;82(12);1499-1507.

[20] Götze R, Boldrin A, Scheutz C, and Astrup TF. Physicochemical characterisation of material fractions in household waste: Overview of data in literature. Waste Management 2016;49:3-14.

[21] Rokni M. Thermodynamic Analysis of an Integrated Gasification Plant with Solid Oxide Fuel Cell and Steam Cycle. J. Green 2012;2(2-3):71-86.

[22] Smith JM, Van Ness HC and Abbott MM 2005. Introduction to chemical engineering thermodynamics. 7th edition, Boston: McGraw-Hill.

[23] Rokni M. Biomass Gasification Integrated with a Solid Oxide Fuel Cell and Stirling Engine. Energy 2014;77:6-18.

[24] Henriksen U, Ahrenfeldt J, Jensen TK, Gøbel B, Bentzen JD, Hindsgaul C and Sørensen LH, The design, construction and operation of a $75 \mathrm{~kW}$ two-stage gasifier. Energy 2006;31(10-11):15421553. 
[25] Rokni M. Thermodynamic analyses of municipal solid waste gasification plant integrated with solid oxide fuel cell and Stirling hybrid system. Hydrogen Energy 2015;40:7855-69.

[26] Channiwala SA and Parikh PP. A unified correlation for estimating HHV of solid, liquid and gaseous fuels. Fuel 2002;81(8):1051-63.

[27] Christiansen N, Hansen JB, Holm-Larsen H, Linderoth S, Larsen PH, Hendriksen PV and Hagen A. Solid oxide fuel cell development at Topsoe fuel cell and Ris $\emptyset$. J Electrochemical Society 2007; 7(1):31-38.

[28] Petersen TF, Houbak N and Elmegaard B. A zero-dimensional model of a 2nd generation planar SOFC with calibrated parameters. Int. J. Thermodynamic 2006;9(4):161-9.

[29] Keegan KM, Khaleel M, Chick LA, Recknagle K, Simner SP, Diebler J. Analysis of a planar solid oxide fuel cell based automotive auxiliary power unit. SAE technical paper series. Paper Nr. 2002-01-0413. DOI: https://doi.org/10.4271/2002-01-0413.

[30] Prentice G. Electrochemical Engineering Principles. Prentice Hall International, Houston, USA, 1991.

[31] Holtappels P, DeHaart LGJ, Stimming U, Vinke IC and Mogensen M. Reaction of CO/CO2 gas mixtures on Ni-YSZ cermet electrode. Applied Electrochemistry 1999;29:561-568.

[32] Zhu H and Kee RJ. A general mathematical model for analyzing the performance of fuel-cell membrane-electrode assemblies. Power Sources 2003;117:61-74.

[33] Costamagna P, Selimovic A, Del Borghi M and Agnew G. Electrochemical model of the integrated planar solid oxide fuel cell (IP-SOFC), Chemical Engineering 2004;102(1):61-69.

[34] Kromp A, Leonide A, Timmermann H, Weber A and Ivers-Tiffée E. Internal Reforming Kinetics in SOFC-Anodes. ECS Transactions 2010;28(11):205-215.

[35] Winnick J. 1997. Chemical engineering thermodynamics, John Wiley \&Sons, New Yourk.

[36] Franchinia G, Notarbartolo E, Padovan LE, Perdichizzi A. Modeling, Design and Construction of a Micro-scale Absorption Chiller. Energy Procedia 2015;82:577-583.

[37] de Vega M, Almendros-Ibanez JA, Ruiz G. Performance of a LiBr-water absorption chiller operating with plate heat exchangers. Energy Conversion and Management 2006;47:3393-3407.

[38] Porumb R, Porumb B, Balan M. Numerical investigation on solar absorption chiller with LiBrH2O operating conditions and performances. Energy Procedia 2017;112:108-117.

[39] Misra RD, Sahoo PK, Gupta A. Thermoeconomic Optimization of a LiBr/H2O Absorption Chiller Using Structural Method. Energy Resources Technology 2005; 127:119-124.

[40] Patek J, Klomfar JA. Computationally effective formulation of the thermodynamic properties of LiBr-H2O solutions from 273 to $500 \mathrm{~K}$ over full composition range. Int. J. of Refrigeration 2006;29(4):566-78.

[41] Incropera FP, DeWitt DP, Bergman TL and Lavine AS. 2013. Foundation of Heat Transfer. $6^{\text {th }}$ ed, Wiley \& Sons, Singapore, ISBN 978-0-470-64616-8. 
[42] Morris M and Waldheim L. Energy recovery from solid waste fuels using advanced gasification technology. Waste Management 1998;18(6-8):557-564.

[43] Babicz J. 2015. Wärtsilä Encyclopedia of Ship Technology. $2^{\text {nd }}$ ed. Wärsilä Corporation, Helsinki, ISBN: 978-952-93-5536-5.

[44] Granryd E, Ekroth I, Lundqvist P, Palm B, Rohlin P. Refrigerating engineering. KTH, Department of Energy Technology. 2011. ISBN 978-91-7415-415-3.

[45] Gilania SIH, Ahmed MSMS. Solution Crystallization Detection for double-effect LiBr-H2O steam absorption chiller. Energy Procedia 2015;75:1522-1528.

[46] van Loo S and Koppejan J. 2008. The handbook of biomass combustion and co-firing. Sterling, London, ISBN: 1281190918.

[47] Hoornweg D and Bhada-Tata P. What a waste: a global review of solid waste management. Technical report, World bank - Urban Development \& Local Government Unit, 2012. URL http://siteresources.worldbank.org/INTURBANDEVELOPMENT/Resources/3363871334852610766/What_a_Waste2012_Final.pdf.

[48] Christensen TH and Fruergaard T.2010. Commercial and Institutional Waste, pages 97-99. John Wiley \& Sons, Ltd. ISBN 9780470666883.

[49] Edjabou ME, Jensen MB, Götze R, Pivnenko K, Petersen C, Scheutz C, and Fruergaard T Astrup. Municipal solid waste composition: Sampling methodology, statistical analyses, and case study evaluation. Waste Management 2015:36;12-23. 